\title{
Allah versus Setan Laplace: Sebuah Usulan Konsep Tindakan Ilahi Khusus yang Trinitarian, Kovenantal dan Saintifik
}

\author{
God versus Laplace's Demon: A Proposal for Trinitarian, \\ Covenantal and Scientific Special Divine Action Concept
}

\author{
David Alinurdin \\ Sekolah Tinggi Teologi SAAT, Malang \\ Korespondensi: david.alinurdin@seabs.ac.id
}

\begin{abstract}
Abstrak: Dalam dekade terakhir, interaksi sains dan teologi dalam upaya membangun konsep tindakan ilahi di dalam dunia natural telah sampai pada satu kesimpulan untuk mencari titik temu kausal di mana Allah Pencipta yang transenden dan nonfisik dapat bertindak di dalam proses-proses natural yang terjadi di dalam dunia ciptaan. Sebuah gerakan akademis yang diakui kredibilitasnya dalam usaha menemukan titik temu kausal dengan cara-cara baru yang memasukkan penafsiran filosofis dari sains kekinian ke dalam teologi adalah Divine Action Project (DAP), yang merumuskan sebuah teori tindakan ilahi yang disebut NIODA (Noninterventionist Objective Divine Action). NIODA berusaha mencari lokus tindakan ilahi khusus yang tidak bertentangan dengan hukum alam yaitu di dalam proses-proses fisik yang dapat ditafsirkan sebagai indeterminisme secara ontologis, seperti mekanika kuantum. Tulisan ini akan mengkaji asumsi-asumsi filosofis di balik NIODA dan memperlihatkan bahwa konsep ini dapat diterima secara saintifik namun tidak memadai secara teologis karena masih terikat dengan asumsi Laplace warisan zaman pencerahan yang menganggap alam semesta ini tertutup secara kausal bagi tindakan ilahi. Karena itu, di bagian terakhir, tulisan ini juga akan mengusulkan beberapa poin penting dalam upaya membangun sebuah konsep tindakan ilahi yang memadai secara teologis maupun saintifik, yang dibangun di atas fondasi teologi penciptaan yang trinitarian dan kovenantal.
\end{abstract}

Kata-kata kunci: Divine Action Project, NIODA, QM-NIODA, Titik Temu Kausal, Tindakan Ilahi Khusus, Indeterminisme, Inkompatibilisme, Nonintervensionis, Setan Laplace, Hukum Alam, Mekanika Kuantum, Transenden, Imanen, Teologi Penciptaan yang Trinitarian-Kovenantal

\begin{abstract}
In the last decade, the interaction between science and theology in the effort to develop the concept of divine action in the natural world has come to a conclusion to find a causal joint where transcendent and nonphysical Creator God can act in natural processes that occur in the world of creation. An academic movement whose credibility has been recognized in its efforts to find a causal joint in new ways that incorporate philosophical interpretations of contemporary science into theology is the Divine Action Project (DAP), which formulates a concept of divine action called NIODA (Noninterventionist Objective Divine Action). NIODA seeks to find a locus of special divine action that does not conflict with laws of nature in physical processes that can be interpreted as ontological indeterminism, such as quantum mechanics. This paper will examine the philosophical assumptions behind NIODA and show that this concept is scientifically acceptable but not theologically adequate because it is still bound by Laplace's assumption of the enlightenment's legacy which considers the universe to be causally closed to divine action. Therefore, in the last part, this paper will also propose several important points in the effort to develop a concept of special divine action that is both theologically and scientifically adequate, built on the basis of a trinitarian and covenantal biblical theology of creation.
\end{abstract}

Keywords: Divine Action Project, NIODA, QM-NIODA, Causal Joint, Special Divine Action, Indeterminism, Incompatibilism, Noninterventionist, Laplace Demon, Laws of Nature, Quantum Mechanics, Transcendence, Immanence, Trinitarian-Covenantal Theology of Creation 


\section{PENDAHULUAN}

Dalam sebuah anekdot diceritakan bahwa kaisar Napoleon terlibat percakapan dengan ahli matematika Perancis bernama PierreSimon Laplace (1749-1827). Laplace baru saja menghasilkan sebuah tulisan yang memperluas karya Newton hingga mencakup keseluruhan sistem tata surya, yaitu Celestial Mechanics yang dipublikasikan pertama kali tahun 1799. Laplace mempresentasikan bukunya tersebut kepada Napoleon. Setelah membacanya sang kaisar bertanya kepada Laplace: "Anda sudah menulis sebuah buku tentang dunia ini tanpa menyebut sedikit pun tentang penciptanya." Laplace menjawab, "Tuan, saya tidak membutuhkan hipotesis tersebut."

Pernyataan Laplace di atas mewakili semangat Pencerahan di abad ke-18 yang menyatakan bahwa alam semesta ini adalah sebuah mekanisme yang impersonal, deterministik dan tertutup bagi tindakan ilahi. Laplace percaya bahwa ia dapat menjelaskan segala sesuatu di alam semesta ini sebagai energi yang bertindak di antara partikel-partikel dan bahwa kalkulasinya memperlihatkan tata surya itu stabil tanpa interferensi dari Allah. ${ }^{2}$ Keyakinan Laplace akan determinisme hukum-hukum di dalam alam semesta ini diungkapkan dalam tulisannya yang terkenal, yaitu:

We ought then to regard the present state of the universe as the effect of its anterior state and as the cause of the one which is to follow. Given for one instant an intelligence which could comprehend all the forces by which nature is animated and the respective situation of the beings that compose it-an intelligence sufficiently

${ }^{1}$ Diceritakan oleh Amir D. Aczel, Why Science Does Not Disprove God? (New York: William Morrow/Harper Collins, 2014), 84-85.

${ }^{2}$ Harry Lee Poe and Jimmy H. Davis, God and the Cosmos: Divine Activity in Space, Time and History (Downers Grove: IVP Academic, 2012), 181. vast to submit these data to analysis-it would embrace in the same formula the movements of the greatest bodies of the universe and those of the lightest atom; for it, nothing would be uncertain and the future, as the past, would be present to its eyes. ${ }^{3}$

Laplace meyakini ada semacam kecerdasan yang disebutnya "intelligent sufficiently vast" yang mampu memahami segala data, daya dan hukum sebab-akibat yang menggerakkan alam semesta, mulai dari atom yang terkecil hingga benda-benda angkasa yang besar. Pikiran yang cerdas ini juga mampu memprediksi apa yang akan terjadi di masa depan berdasarkan apa yang telah terjadi di masa lalu.

Pikiran cerdas Laplace yang seringkali disebut dengan istilah Laplace's Demon ini mewakili cara pandang sains, baik pada masa itu maupun hingga masa kini, yang sangat deterministik dan tidak menyisakan ruang sedikit pun bagi tindakan Allah di dalam alam semesta. Penyelidikan sains dari hari ke hari semakin berhasil menemukan pola keteraturan dan mekanisme (yang empiris, dapat diverifikasi dan diprediksi) di balik semua fenomena yang terjadi di dunia ini, termasuk pengalaman religius akan aktivitas ilahi. ${ }^{4}$ Melihat kenyataan ini, para sarjana, filsuf maupun teolog yang mempelajari konsep tindakan ilahi dalam interaksi antara sains natural dan teologi, berusaha mencari titik temu kausal (causal joint) di mana Allah Pencipta yang transenden dan nonfisik dapat bertindak di dalam realita prosesproses fisik yang terjadi di dalam dunia ciptaan. ${ }^{5}$ Salah satu gerakan akademis yang berusaha menemukan causal joint dengan

${ }^{3}$ Pierre-Simon Laplace, A Philosophical Essay on Probabilities (London: John Wiley and Sons, 1902), 4.

${ }^{4}$ Sarah Lane Ritchie, Divine Action and the Human Mind (Cambridge: Cambridge University Press, 2019), bab 1, kindle.

${ }^{5}$ Sarah Lane Ritchie, "Dancing Around the Causal Joint: Challenging the Theological Turn in Divine Action Theories," Zygon 52, no. 2 (2017): 362. 
cara-cara baru yang menggabungkan penafsiran tertentu dari teori-teori sains yang sedang berkembang ke dalam teologi Kristen adalah Divine Action Project.

Divine Action Project (selanjutnya disingkat DAP) adalah hasil dari seruan Paus Yohanes Paulus II kepada para sarjana dari berbagai disiplin ilmu untuk mengadakan konferensi yang berfokus pada hubungan antara teologi dan sains. ${ }^{6}$ Gerakan yang disponsori oleh Vatican Observatory (VO) bekerja sama dengan Center for Theology and Natural Sciences (CTNS) ini berkembang menjadi proyek selama 20 tahun (1988-2008) berupa konferensi antar disiplin ilmu (seperti fisika, kosmologi, biologi, filsafat agama, filsafat sains, teologi sistematika, sejarah teologi dan sejarah sains) dan penerbitan lima buku mengenai tindakan ilahi dalam satu seri yang diberi tajuk Scientific Perspectives on Divine Action, satu buku pengantar dan satu buku penutup. $^{7}$ Robert John Russell, seorang fisikawan dan teolog dari CTNS, ditunjuk sebagai ketua dari proyek ini dan juga editor umum dari beberapa buku yang diterbitkan. Selain Russell, beberapa sarjana terkemuka yang menjadi pionir dan terlibat dalam proyek ini adalah Arthur Peacocke, Ian Barbour, John Polkinghorne dan Nancey Murphy. Bukanlah sesuatu yang berlebihan untuk menyatakan bahwa proyek ini memiliki signifikansi khusus dengan memperlihatkan bahwa tindakan ilahi menjadi topik yang berharga untuk dibicarakan karena menjadi

\footnotetext{
${ }^{6}$ Mengenai latar belakang sejarah, analisis dan sinopsis dari DAP dapat dilihat pada Wesley J. Wildman, "The Divine Action Project, 1988-2003," Theology and Science 2, no. 1 (2004): 31-75, dan Kile Jones, "Falsifiability and Traction in Theories of Divine Action," Zygon 45, no. 3 (2010): 575-589.

${ }^{7}$ Kelima judul buku tersebut adalah Quantum Cosmology and the Laws of Nature (1993), Chaos and Complexity (1996), Evolutionary and Molecular Biology (1996), Neuroscience and the Person (1999) dan Quantum Mechanics (2002). Satu buku pengantar yang diterbitkan paling pertama adalah Physics, Philsophy, and Theology: A Common Quest for Understanding (1988) dan buku terakhir yang diterbitkan adalah Scientific Perspectives on Divine Action: Twenty Years of Challenge and Progress (2008).
}

semacam penghubung utama yang mempertemukan disiplin ilmu teologi dan sains.

Fokus perhatian DAP adalah mencari titik temu kausal yang indeterministik ${ }^{8}$ dengan daya tarik maksimal (maximum traction) ${ }^{9}$ antara sains dan teologi demi mendemonstrasikan konsep tindakan ilahi yang kredibel secara saintifik dan juga dapat diterima secara teologis. DAP membagi tindakan ilahi menjadi tiga jenis, yaitu: tindakan ilahi umum, tindakan ilahi khusus dan mukjizat. ${ }^{10}$ Yang menjadi fokus penyelidikan DAP adalah tindakan ilahi khusus. Hasil utama dari DAP adalah menelurkan suatu konsep tindakan ilahi khusus yang langsung, objektif dan diperantarai oleh peristiwa-peristiwa di dalam dunia natural, yang disebut sebagai Noninterventionist Objective Divine Action (selanjutnya disingkat NIODA). ${ }^{11}$ Dari beberapa pendekatan NIODA yang diusulkan dalam proyek ini, ${ }^{12}$ pendekatan yang saat ini dianggap sebagai standar yang paling memungkinkan untuk menjelaskan tindakan

${ }^{8}$ Para sarjana di dalam DAP berusaha mencari titiktitik di dalam rantai kausalitas dunia fisik yang memperlihatkan semacam anomali yang indeterministik, yaitu suatu akibat yang tidak dihasilkan oleh penyebab kausal tertentu. Hal ini akan dijelaskan lebih jauh.

${ }^{9}$ Wesley J. Wildman, "Robert John Russell's Theology of God's Action," dalam God's Action in Nature's World, ed. Ted Peters dan Nathan Hallanger (New York: Routledge, 2016), 154.

${ }^{10}$ Wildman, "The Divine Action Project," 37-38. Tindakan ilahi umum (general divine action atau GDA) adalah tindakan Allah yang menciptakan dan menopang semua realitas yang ada di alam semesta ini sejauh tidak membutuhkan providensi dengan intensi dan tujuan yang khusus. Tindakan ilahi khusus (special divine action atau SDA) adalah tindakan providensi Allah yang spesifik, yang secara khusus dipertimbangkan dan dimaksudkan untuk terlaksana di dalam dunia, baik pada waktu dan tempat tertentu, maupun di segala waktu dan tempat. Mukjizat sangat sedikit mendapat perhatian dalam DAP karena dianggap tindakan Allah yang berupa intervensi.

${ }^{11}$ Robert J. Russell, "Challenge and Progress In 'Theology And Science': An Overview Of The CTNS/VO Series," dalam Philosophy, Science and Divine Action, ed. F. Leron Shults, Nancey Murphy, dan Robert J. Russell (Leiden: Brill, 2009), 416.

${ }^{12}$ Selain QM-NIODA, pendekatan-pendekatan NIODA lainnya adalah teori Chaos dari John Polkinghorne dan kausalitas top-down dari Arthur Peacocke. 
ilahi dari perspektif sains adalah NIODA yang didasarkan pada mekanika kuantum (atau yang biasa disingkat QM-NIODA, singkatan dari Quantum Mechanic based Noninterventionist Objective Divine Action). ${ }^{13}$

Tulisan ini akan mengkaji asumsi-asumsi filosofis di balik pendekatan NIODA (atau secara khusus QM-NIODA) dan memperlihatkan bahwa pendekatan NIODA dan juga para sarjana yang mencetuskannya masih terikat di dalam asumsi "Setan Laplace" sehingga konsep tindakan ilahi yang diusulkan lebih condong supaya diterima secara saintifik namun tidak memadai secara teologis. Konsep tindakan ilahi yang memadai secara teologis mampu menjembatani transendensi Allah dan imanensi dunia ciptaan ${ }^{14}$ serta menonjolkan keaktifan ${ }^{15}$ Allah yang memengaruhi dan mengarahkan jalannya

\footnotetext{
${ }^{13}$ Wildman, "The Divine Action Project," 50. Jeffrey Koperski mengatakan, "Today, many noninterventionist view God actively governs, but does so ... without violating any laws of nature. The most popular version of this is what I will call quantum determination," yang bisa dilihat dalam "The Quantum Amplification Problem Appears to Be Unsolvable," Theology and Science 13, no. 4 (2015): 379.

${ }^{14}$ Simon J.S. Cross, "Perspectives on Divine Action: Reflections on the Theological Legitimacy of Approaches to Divine Action in the V.O./C.T.N.S. Series 'Scientific Perspectives on Divine Action"' (disertasi, University of Oxford, 2017), 24-26. Menurut Cross, transenden di sini memiliki pengertian bersifat nonfisik dan melampaui instrumen-instrumen penyelidikan sains, dan imanen memiliki pengertian bersifat fisik dan, secara teori, dapat dideteksi oleh instrumen-instrumen penyelidikan sains.

${ }^{15}$ Andrew Jacobs mengusulkan kriteria ini dengan alasan berikut: "In general, two options have been open to the theologian: eschew scientific determinism and assert the special activity of God in spite of contravening opinions, or attempt to develop a theory of divine action that defers to prevailing scientific and philosophical worldviews. ... The second option averts these problems, yet has historically suffered from theological inadequacy in that its proponents have often give up important tenets of the Christian faith in order to develop models that are compatible with scientific presuppositions about reality. The criterion of 'theological adequacy' in this context evaluates the extent to which a theological presentation of divine action, in its effort to be adequate to the Christian tradition and its proclamation of an active God, should strive to intelligibly defend the claim that God directs the world towards the divine purpose." Lebih lanjut lihat Andrew Jacobs, "The Creative Power of the Future: Wolfhart Pannenberg, Modern Science, and the Metaphysics of Divine Action" (disertasi, Fordham University, 2009), 52.
}

sejarah untuk mencapai tujuan ilahi yang dikehendaki-Nya. Karena itu, tulisan ini juga akan mengusulkan beberapa poin penting di dalam membangun konsep tindakan ilahi yang memadai secara teologis, yang dibangun di atas fondasi teologi penciptaan yang trinitarian dan kovenantal.

\section{MENGKAJI ASUMSI-ASUMSI FILOSOFIS DI BALIK NIODA}

Sebagai tokoh penting dalam DAP yang mencetuskan NIODA, Russell merumuskannya sebagai berikut:

Specifically, we will seek to speak about special divine acts in which God acts objectively in an unusual and particularly meaningful way in, with, and through events which serve to mediate God's action. We will seek to do so without entertaining-in fact by refusing-the additional claim that God must intervene in, or at least suspend, the laws of nature (which are themselves the result of and description of God's continuous creation). I call this type of divine action noninterventionist view of objective special providence or noninterventionist objective divine action $(N I O D A) .{ }^{16}$

Untuk mewujudkan sebuah konsep NIODA yang berhasil dan kredibel secara saintifik, DAP mengarahkan pencarian mereka kepada domain teori-teori sains yang secara filosofis dapat ditafsirkan sebagai indeterminisme secara ontologis. Mewakili DAP, Russell menjelaskan kriteria NIODA yang berhasil adalah sebagai berikut:

For noninterventionist objective divine action to be intelligible in light of science, the events that result from God's action must occur within a domain of nature in which the appropriate scientific theory can

\footnotetext{
${ }^{16}$ Robert John Russell, Cosmology: From Alpha to Omega (Minneapolis: Fortress, 2008), 117.
} 
be interpreted philosophically in terms of ontological indeterminism. ${ }^{17}$

Dari definisi ini dapat disimpulkan bahwa di balik konsep NIODA terdapat asumsiasumsi bahwa tindakan ilahi khusus tersebut harus bersifat inkompatibel dengan hukumhukum alam yang diyakini bersifat ontologis sehingga, supaya bisa diterima secara saintifik, tindakan ilahi tersebut harus memiliki ciri-ciri nonintervensionis dan indeterministik secara ontologis. Dari definisi di atas terlihat ada empat asumsi filosofis DAP, yaitu: indeterminisme secara ontologis, nonintervensionis, hukum alam yang ontologis dan inkompatibilisme sebagai akar dari ketiga asumsi lainnya. Keempat hal inilah yang akan dikaji selanjutnya.

\section{Indeterminisme secara Ontologis}

Sebagai sebuah kriteria NIODA yang berhasil, Russell dan para sarjana di DAP menetapkan bahwa sebuah tindakan ilahi khusus yang kredibel secara saintifik harus bersifat indeterministik secara ontologis, ${ }^{18}$ yang artinya tidak ada penyebab efisien natural apa pun yang cukup untuk menghasilkan suatu proses atau peristiwa di dalam dunia fisik. Karena sifatnya yang indeterministik secara ontologis maka tindakan ilahi versi NIODA ini akan tersembunyi dari sains dan tampak sebagai serangkaian peristiwa chance yang dideskripsikan secara matematis sebagai probabilitas. ${ }^{19}$ Salah satu bentuk tindakan ilahi yang ditafsirkan DAP bersifat indeterministik secara ontologis

\footnotetext{
${ }^{17}$ Russell, Cosmology, 125.

${ }^{18}$ Russell mendefinisikan indeterminisme secara ontologis sebagai "the philosophical interpretation of nature according to which there may not always be an efficient physical cause for every effect." Penjelasan lebih rinci mengenai hal ini dapat dilihat dalam Cosmology, 120.

${ }^{19}$ Russell berkata, "God's direct action according to NIODA will be hidden in principle from science even if science were to search for it. This is because, for each event in question, there is no natural efficient cause for science to discover, given that the scientific theory in question is interpreted philosophically as pointing to ontological indeterminism" (ibid., 128, 169).
}

adalah QM-NIODA, atau tindakan ilahi di dalam peristiwa pengukuran mekanika kuantum. Para sarjana DAP cenderung menerima penafsiran Copenhagen yang memahami peristiwa pengukuran kuantum sebagai sebuah ketidakpastian yang objektif (objective uncertainty) dan kemungkinan yang objektif (objective chance) ${ }^{20}$ Mereka meyakini bahwa ketidakpastian ini bukan disebabkan oleh kurangnya pengetahuan dari peneliti atau ketidaktepatan dari alat ukur yang digunakan, melainkan karena indeterminasi yang ada di dalam realita fisik itu sendiri.

Dengan berpegang pada asumsi indeterminisme secara ontologis dari penafsiran Copenhagen, para penggagas QM-NIODA sepertinya sedang mengatakan bahwa tidak ada penyebab efisien apapun (termasuk tindakan ilahi) di dalam peristiwa pengukuran mekanika kuantum. Keyakinan ini justru bertentangan dengan doktrin Kristen mengenai penciptaan ex nihilo yang menyatakan bahwa segala sesuatu di alam semesta ini bergantung penuh kepada Allah sebagai prima causa dari seluruh eksistensi yang ada. Jika Allah adalah Pribadi yang rasional, bagaimana mungkin Ia menciptakan irasionalitas yang indeterministik di dalam dunia ini? Lebih jauh lagi, jika Ia menciptakan indeterminisme di dalam dunia ini, bagaimanakah Ia dapat mengatur seluruh ciptaanNya? Nicholas Saunders menggambarkan kesulitan ini sebagai berikut:

Indeed, at first sight, it seems difficult to see in what sense indeterminism might be created and sustained by God or, to put it another way, how indeterminism and general divine action might be related. Given the common assumption that the indeterministic processes form part of the physical universe we inhabit, we naturally beg the

\footnotetext{
${ }^{20}$ William Stoeger, "Epistemological and Ontological Issues Arising from Quantum Theory," dalam Quantum Mechanics: Scientific Perspectives on Divine Action, ed. Robert John Russell et al. (Vatican City: Vatican Observatory Publication, 2001), 88-90.
} 
question as theologians to describe how God is related to those processes. Indeed the only sense in which indeterminism appears coherent is as a product of a divine kenosis, or God voluntarily withholding his knowledge, concerning its mechanism. However if this is the case then we must address the problem of how God is active in some indeterminate processes without compromising this mechanism or his lack of knowledge of it. ${ }^{21}$

Namun, jika ditelusuri lebih lanjut, Russell dan para penggagas QM-NIODA sebenarnya memiliki keyakinan bahwa Allah dapat bertindak secara khusus di dalam peristiwaperistiwa alam yang ditafsirkan sains sebagai indeterminisme secara ontologis, karena itulah sebenarnya motivasi dan tujuan mereka mencetuskan NIODA. Dengan demikian terlihat bahwa para sarjana DAP pencetus NIODA sebenarnya masih bersikap ambigu di dalam konsep tindakan ilahi yang mereka usulkan. Dodd menjelaskan ambiguitas ini sebagai berikut:

The argument appears seamless. If we look more closely, however, we may find that proponents of quantum divine action are able to introduce God as the cause of quantum events only by abandoning the Copenhagen interpretation and adopting $a$ sort of hybrid interpretation that includes elements of both the Copenhagen interpretation and that of its opponents. Scientists solidly situated in the Copenhagen interpretation believe that no causes are needed for quantum events. Scientists who oppose the Copenhagen interpretation believe that natural causes are needed and should be sought through the usual methods of empirical science. The first group would be puzzled by the postulation of a divine cause for quantum events, since no cause is needed. The second group would

\footnotetext{
${ }^{21}$ Nicholas Saunders, Divine Action and Modern Sci-
} ence (Cambridge: Cambridge University Press, 2002), 90. wonder at the introduction of a divine cause for quantum events since what is needed is a natural cause. ${ }^{22}$

Sikap ambigu para sarjana penggagas NIODA ini sebenarnya berakar dari asumsi filosofis mereka bahwa tindakan ilahi khusus di dalam dunia harus bersifat nonintervensionis. Hal inilah yang akan dikaji selanjutnya.

\section{Nonintervensionis}

Para sarjana yang tergabung dalam DAP sepakat bahwa tindakan Allah di dalam dunia tidak boleh mengintervensi (melanggar, melampaui atau membatalkan $)^{23}$ hukum-hukum alam yang sudah ditetapkanNya sejak Ia menciptakan alam semesta ini. ${ }^{24}$ Para sarjana DAP berpandangan bahwa jika Allah bertindak di dalam dunia dengan melanggar hukum-hukum alam maka Ia tidak konsisten atau berubah-ubah. John Polkinghorne, seorang teolog dan ilmuwan dari Cambridge yang tergabung dalam DAP, menyatakan kepeduliannya akan hal ini sebagai berikut:

Two general conditions must surely apply to any adequate account of divine action. The first is that it must be continuous and not fitful, correctly referred to as inter-

${ }^{22}$ Michael J. Dodds, Unlocking Divine Action (Washington: The Catholic University of America Press, 2017), 144-145.

${ }^{23}$ Mengenai "violating the laws" lihat Wildman, "Divine Action Project," 50. Tentang "setting aside natural law" lihat Philip Clayton, "Wildman's Kantian Skepticism: A Rubicon for the Divine Action Debate," Theology and Science 2, no. 2 (2004): 187. Mengenai "overriding" hukum-hukum alam dapat dilihat dalam Thomas Tracy, "Scientific Perspectives on Divine Action? Mapping the Options," Theology and Science 2, no. 2 (2004): 197.

${ }^{24}$ Wildman berkata, "The DAP project tried to be sensitive to issue of theological consistency ... the idea of God sustaining nature and its law-like regularities with one hand while miraculously intervening, abrograting, or ignoring those regularities with the other hand struck most members as dangerously close to outright contradiction. Most participants certainly felt that God would not create an orderly world in which it was impossible for the creator to act without violating the created structures of order" ("The Divine Action Project," 38). 
action' rather than 'intervention.' There can be nothing capricious or occasional in God's activity. ${ }^{25}$

Senada dengan Pokinghorne, Russell menyatakan keberatannya terhadap intervensi tindakan Allah sebagai berikut:

The problem with intervention is that it suggests that God is normally absent from the web of natural processes, acting only in the gaps that God causes. Furthermore, since God's intervention breaks the very processes of nature which God created and constantly maintains, it pits God's special acts against God's regular action, which underlies and ultimately causes nature's regularities. ${ }^{26}$

Dua pernyataan di atas memperlihatkan DAP menganut pandangan bahwa tindakan ilahi khusus (SDA) tidak boleh bertentangan dengan tindakan ilahi umum (GDA). Hal ini dijelaskan Taede A. Smedes sebagai berikut:

To argue that God works against the laws of nature, or suspends them temporarily, would make the concept of God inconsistent. If in general providence God acted continuously through the nexus of secondary causality in accord with the laws of nature, and if at the same time God worked against these laws by putting them temporarily out of order, the action would be internally inconsistent: God's special action would work against God's general action. ${ }^{27}$

${ }^{25}$ John C. Polkinghorne, "Chaos Theory and Divine Action" dalam Religion and Science: History, Method, Dialogue, ed. Mark W. Richardson and Wesley J. Wildman (New York: Routledge, 1996), 244.

${ }^{26}$ Robert J. Russell "Quantum Physics and the Theology of Non-Interventionist Objective Divine Action," dalam The Oxford Handbook of Religion and Science, ed. Philip Clayton dan Zachary Simpson (Oxford: Oxford University Press, 2006), 584.

${ }^{27}$ Taede A. Smedes, "Beyond Barbour or Back to Basics? The Future of Science-and-Religion and the Quest for Unity," Zygon 43, no. 1 (2008): 243.
Karena alasan di atas maka DAP mengusulkan NIODA sebagai sebuah model tindakan ilahi yang bersifat nonintervensionis demi memperlihatkan karakter Allah yang konsisten dan dapat diandalkan. Yang menyebabkan para sarjana DAP menolak intervensi tindakan ilahi di dalam dunia ini adalah tambahan metafisik atau filosofis terhadap pandangan sains mengenai dunia ini. Tambahan metafisik atau filosofis terhadap pandangan sains klasik tersebut berasal dari Pierre-Simon Laplace. Hal inilah yang dicermati oleh Plantinga, yang mengatakan:

What actually guides their thought is not classical science as such, but classical science plus gratuitous metaphysical or theological addition-one that has no scientific credentials and goes contrary to classical Christianity. ${ }^{28}$

Sebenarnya asumsi filosofis yang ditambahkan Laplace kepada determinisme dari mekanika klasik Newton adalah tertutupnya alam semesta secara kausal. ${ }^{29}$ Plantinga mengatakan bahwa Laplace berasumsi bahwa Allah tidak dapat atau tidak akan bertindak secara khusus dan juga bahwa hukumhukum alam bersifat deterministik, nonprobabilistik dan lengkap, dengan tujuan untuk memperlihatkan kehebatan dari "Setan Laplace" yang diusulkannya. ${ }^{30}$ Dengan demikian, "Setan Laplace" mengasumsikan alam semesta harus bersifat tertutup secara kausal dan hukum-hukum alam harus bersifat deterministik supaya ia bisa memprediksikan dan mendeduksi keadaan alam semesta pada waktu-waktu tertentu. Karena itu, gambaran alam semesta yang dibangun berdasarkan pandangan fisika klasik yang bercampur metafisik Laplace ini tidak memberikan ruang

${ }^{28}$ Alvin Plantinga, Where The Conflict Really Lies: Science, Religion, and Naturalism (Oxford: Oxford University Press, 2011), 84.

${ }^{29}$ Plantinga menyebutnya sebagai "the causal closure of the physical universe" (ibid., 85).

${ }^{30}$ Ibid., 85-86. 
bagi tindakan Allah secara khusus. Kalau demikian, seperti apakah pandangan sains klasik yang asli mengenai alam semesta, yang tidak dipengaruhi oleh pandangan Laplace?

Fisika klasik yang dipengaruhi oleh pandangan Newton sebenarnya tidak bersifat tertutup secara kausal bagi intervensi. Newton memang mengibaratkan dunia ini sebagai sebuah sistem mekanika yang diatur oleh hukum-hukum fisika. Namun, mekanika Newton atau sains klasik tidak pernah menyatakan bahwa alam semesta ini adalah sistem yang tertutup. Malahan Newton sendiri percaya bahwa Allah di dalam providensiNya memandu dunia ini. Misalnya Allah secara teratur menyetel orbit dari planetplanet karena menurut kalkulasi Newton, orbit-orbit planet itu "would otherwise spiral off into chaos." 31 Menurut Newton, Allah bertindak di dalam alam semesta ini berdasarkan keputusan kehendak-Nya sebagai "powerful ever-living Agent, who being in all Places, is more able by his Will to move the Bodies within his boundless uniform Sensorium, and thereby to form and reform the Parts of the Universe, than we are by our Will to move the Parts of our own Bodies." 32 Jika alam semesta tidak tertutup secara kausal, maka apakah argumentasi DAP (tindakan ilahi khusus tak boleh bersifat intervensionis dengan alasan hal tersebut memperlihatkan ketidakkonsistenan Allah yang berubahubah dalam kehendak dan tindakan-Nya) dapat dibenarkan?

Fakta bahwa kita tidak bisa melihat pola atau alasan mengapa Allah di suatu saat melakukan tindakan yang "mengintervensi" hukum-hukum alam tetapi di saat yang lain tidak, tidak menunjukkan bahwa Allah tidak punya alasan ketika melakukan hal tersebut. Jika kita memiliki kemampuan untuk mengetahui dan mencermati segala sesuatu

\footnotetext{
${ }^{31}$ Plantinga, Where the Conflict Really Lies, 77, 79.

${ }^{32}$ Isaac Newton, Opticks (1730; repr., New York: Dover, 1952), 403.
}

yang terjadi di dalam dunia ini secara komprehensif dari sudut pandang Allah, maka tindakan Allah yang sebelumnya kita anggap plinplan, sekarang jadi terlihat sangat beralasan dan masuk akal. Peter Harrison mengatakan bahwa hal inilah yang disadari oleh para voluntaris ${ }^{33}$ di abad pertengahan. Mereka mengenali perbedaan antara providensi biasa dengan providensi luar biasa sebagai "function of incomplete human knowledge." ${ }^{34}$ Mereka memandang mukjizat terjadi berdasarkan pola yang sah dan sudah ditetapkan sebelumnya sehingga ketidakmampuan untuk mencocokkan mukjizat ke dalam pola hukum-hukum alam adalah akibat dari keterbatasan pengetahuan dan pemahaman manusia, bukan disebabkan oleh perbedaan di dalam mode operasi Allah.

Para sarjana DAP yang nonintervensionis menilai Allah tidak konsisten di dalam pilihan kehendak yang dibuat-Nya, ketika di satu sisi Ia memilih menetapkan hukum-hukum alam dan secara terus-menerus menopang alam semesta ini dengan hukum-hukum tersebut, namun di sisi lain juga memilih untuk melanggar hukum-hukum yang sama. Namun, berbicara mengenai kehendak dari satu pribadi (baik manusia, apalagi Allah) adalah hal yang kompleks, berlapis-lapis dan juga bergantung pada konteks keadaan yang terjadi. Misalnya, manusia lazimnya memiliki kehendak secara umum untuk bebas dari rasa sakit, namun seseorang yang menyukai olahraga berisiko tinggi tetap memilih untuk melakukan hobinya tersebut walaupun mengetahui ada risiko terluka, terjatuh atau bahkan mengalami penderitaan yang lebih besar lagi. Sama halnya dengan itu, Allah bisa saja memiliki kehendak umum untuk mengatur alam semesta ini melalui hukum-

\footnotetext{
${ }^{33}$ Voluntarisme secara sederhana berarti pandangan yang berpendapat bahwa Allah dapat memilih melakukan apapun yang dikehendaki-Nya tanpa dibatasi oleh esensi-Nya. Lihat Jeffrey Koperski, The Physics of Theism: God, Physics and The Philosophy of Science (Chichester: Wiley-Blackwell, 2015), 15.

${ }^{34}$ Peter Harrison, "Voluntarism and Early Modern Science," History of Science 40, no. 1 (2002): 79.
} 
hukum alam. Meski demikian, untuk alasanalasan tertentu yang tidak bisa dimengerti oleh keterbatasan pikiran manusia, Allah masih mengizinkan terjadinya pengecualianpengecualian khusus. Dalam hal ini tidak ada satu pun, baik sang penggemar olahraga berisiko maupun Allah sendiri, yang bisa dikatakan tidak konsisten karena konflik kehendak. Jika diselidiki lebih jauh lagi maka asumsi filosofis yang mendasari DAP menetapkan NIODA bersifat nonintervensionis adalah pemahaman mengenai hukum alam yang bersifat ontologis dan preskriptif. ${ }^{35}$

\section{Hukum Alam yang Ontologis dan Preskriptif}

Sejak awal, perdebatan klasik di antara sains dan teologi mengenai konsep tindakan ilahi terletak pada pemahaman terhadap natur dari hukum-hukum alam itu sendiri, apakah bersifat deskriptif ${ }^{36}$ atau preskriptif. ${ }^{37} \mathrm{Se}$ sungguhnya sangat mengherankan jika para sarjana DAP, yang telah menyelidiki perubahan paradigma dari fisika klasik menuju fisika kuantum dan merayakan keterbukaan

${ }^{35}$ Niels Henrik Gregersen mengatakan bahwa konsep hukum alam yang preskriptif menjadi semacam halangan yang berakibat pada terbentuknya ide tindakan ilahi khusus yang nonintervensionis. Lebih detil mengenai hal ini dapat dilihat dalam "Divine Action and the Quilt of Laws: Why the Distinction between General and Special Divine Action Cannot Be Maintained," dalam Scientific Perspectives on Divine Action: Twenty Years of Challenge and Progress, ed. Robert John Russell, Nancey Murphy, dan William R. Stoeger (Notre Dame: University of Notre Dame Press, 2008), 191.

${ }^{36}$ Para sarjana yang menganut pandangan hukum alam deskriptif melihat hukum-hukum tersebut sebagai deskripsi dari keteraturan-keteraturan yang sesungguhnya terjadi di alam semesta atau kemampuan alam itu sendiri untuk menghasilkan kausalitas yang efektif (causal efficacy).

${ }^{37}$ Para sarjana yang menganut pandangan hukum alam secara preskriptif memahami hukum alam tersebut bersifat ontologis. Karena itu, mereka meyakini adanya hukum-hukum alam yang sesungguhnya (aktual) yang, hanya sebagian dan untuk sementara waktu saja, direpresentasikan oleh hukum-hukum yang ada di dalam teori-teori sains. Hukum-hukum alam aktual ini dikatakan "memerintah" proses-proses alam secara preskriptif dan proses-proses alam itu "patuh" kepada hukumhukum alam aktual tersebut. alam semesta yang dicirikan oleh probabilitas dan indeterminisme secara ontologis, masih menganggap hukum-hukum alam sebagai pembatas bagi tindakan ilahi khusus sehingga mereka merasa harus tetap merumuskan sebuah konsep tindakan ilahi khusus yang nonintervensionis.

Dalam hal ini, sekali lagi terlihat sikap ambigu dari para sarjana DAP: di satu sisi menganggap alam semesta terbuka bagi tindakan ilahi, namun di sisi lain, menganggap hukum alam bersifat ontologis dan preskriptif. ${ }^{38}$ Russell sendiri secara pribadi terlihat ambigu dan tidak konsisten dalam memahami hukum alam. Meskipun ia cenderung memandang hukum-hukum alam bersifat deskriptif namun ia sendiri juga mengakui bahwa ketika masuk ke dalam konteks diskusi antara sains dan teologi, ia cenderung melihat hukum-hukum alam itu secara ontologis, preskriptif dan normatif. Ia mengakui hal ini dengan mengatakan:

I tend to view the laws of nature in the latter, descriptive sense. At times, though, I use the language of 'nature obeying' such laws in order to make a specific methodological point: that I (and others in theology and science) must take seriously and stick with the consequences of a given scientific theory even if these mitigate against my theological position. If I am to 'play the game' of theology and science fairly, then I had best use sparingly —as a rare fallback strategy-any move which says the laws are mere descriptions and cannot apply apodically or normatively in all cases.' Such a move might save the day for theology, but in only does so by threatening to end the discussion with science. ${ }^{39}$

\footnotetext{
${ }^{38}$ Ritchie menyebut para sarjana DAP menganut pandangan tentang hukum alam yang ontologis dan preskriptif ketika mengatakan, "And indeed, DAP-style divine action theorist have often assumed a necessitarian model of physical laws" (Divine Action, bab 2, kindle).

${ }^{39}$ Russell, Cosmology, 120.
} 
Melihat sikap ambigu DAP di atas, bagaimanakah seharusnya pemahaman yang tepat terhadap hukum-hukum alam? Newton dan mekanika klasik memang menyatakan bahwa hukum-hukum alam menggambarkan bagaimana dunia bekerja secara deterministik sebagai sebuah sistem yang tertutup atau terisolasi dari pengaruh-pengaruh kausal luar $^{40}$ namun hal ini tidak berarti sains klasik sedang bermaksud mengatakan bagaimana dunia ini selalu bekerja. Sains klasik hanya menjelaskan bagaimana segala sesuatu bekerja menurut hukum-hukum alam pada saat alam semesta ini tertutup secara kausal, tetapi sama sekali tidak bersikap dogmatis bahwa alam semesta tertutup secara kausal. John Mackie, seorang filsuf penentang teisme, justru bisa menangkap poin ini ketika mengatakan:

What we want to do here is to contrast the order of nature with a possible divine or supernatural intervention. The laws of nature, we must say, describe the ways in which the world-including, of course, human beings-works when left to itself, when not interfered with. A miracle occurs when the world is not left to itself, when something distinct from the natural order as a whole intrudes into it. ${ }^{41}$

Pernyataan ini justru memberikan penjelasan yang tepat mengenai hukum-hukum alam yang sesuai dengan gambaran sains klasik. Dengan demikian, hukum-hukum alam tersebut tidak menjadi ancaman bagi tindakan ilahi khusus.

Hukum-hukum alam seharusnya tidak dipahami secara ontologis, melainkan sebagai deskripsi dari keteraturan-keteraturan di dalam alam yang dihasilkan dan ditopang oleh tindakan Allah Pencipta yang setia dan

\footnotetext{
${ }^{40}$ Plantinga, Where the Conflict Really Lies, 78.

${ }^{41}$ John L. Mackie, The Miracle of Theism: Arguments for and against the Existence of God (New York: Oxford University Press, 1982), 19-20. Penekanan oleh penulis.
}

dapat dipercaya. Jika hukum-hukum alam itu hanya bersifat deskriptif dan derivative maka hukum-hukum tersebut tidak punya entitas sendiri ${ }^{42}$ atau keberadaan yang independen dari Allah Sang Pencipta. Karena tidak punya entitas atau keberadaan yang independen, maka hukum-hukum alam tersebut tentu saja tidak mungkin bisa dilanggar oleh Allah ketika Ia bertindak dalam dunia ini. Koperski mengatakan:

There is no sense in which God might suspend the laws of nature taken as regularities, since the laws themselves are nothing more than the way things normally behave. Strictly speaking, regularity-based laws don't exist in such a way that they could be broken. There literally isn't anything "out there" to be broken. ${ }^{43}$

Bagi Newton, alam semesta bukanlah produk dari pergerakan-pergerakan atom yang tanpa arah, melainkan hasil dari pilihan dan keputusan ilahi yang mengatur alam semesta ini melalui hukum-hukum yang telah ditetapkan-Nya. ${ }^{44}$ Karena itu, bagaimana mungkin tindakan ilahi khusus dapat dikatakan tidak melanggar hukum-hukum alam? Saat Allah bertindak secara khusus (misalnya melakukan mukjizat), kondisi alam semesta tidak tertutup secara kausal. Tidak ada hukum-hukum alam yang berlaku pada saat itu. Karena itu, dapat disimpulkan, menurut sains klasik, ketika Allah melakukan tindakan ilahi khusus, Ia tidak sedang melanggar hukum-hukum alam. ${ }^{45}$ Dengan demikian, asumsi lama bahwa sains klasik warisan

${ }^{42}$ Pengertian derivative di sini artinya hukum-hukum alam tersebut bergantung pada keberadaan alam semesta. Jika alam semesta ini tidak ada, maka tentu saja hukumhukum alam itu juga tidak ada. Karena itu, hukumhukum alam tersebut tidak memiliki entitas sendiri.

${ }^{43}$ Koperski, The Physics of Theism, 158-159.

${ }^{44}$ John Hedley Brooke, "Divine Providence in the Clockwork Universe," dalam Abraham's Dice: Chance and Providence in the Monotheistic Traditions, ed. Karl W. Giberson (New York: Oxford University Press, 2016), 227.

${ }^{45}$ Plantinga, Where the Conflict Really Lies, 83. 
Newton bersifat tertutup secara kausal adalah salah. Di dalam dunia ruang-waktu Newton, alam semesta tidak otomatis tertutup dalam pengertian operatif, yakni tertutup pengaruh-pengaruh dari luar. Bahkan mekanika klasik mengizinkan partikel-partikel dari lokasi yang jauh tak terhingga untuk memasuki ruang angkasa bumi. Koperski mengatakan,

A Laplacian demon would not be able to predict the arrival of such particles, yet no laws of nature would be broken by such and event. The laws would simply make room for the particles once they were here. In sum, deterministic laws of nature in no way forbid God's direct causal influence. $^{46}$

Keterbukaan alam semesta secara kausal juga dapat diamati melalui fenomena-fenomena yang terjadi di dalam dunia sehari-hari seperti berikut ini. ${ }^{47}$ Ambil contoh misalnya roda kereta api pada gambar di bawah ini.
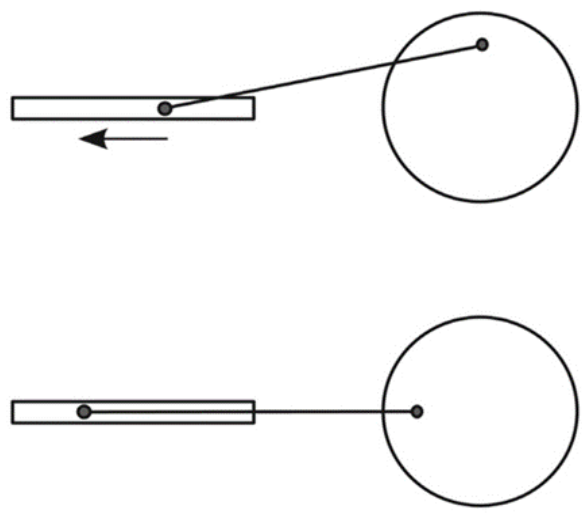

Gambar 1 Roda kereta api yang sedang bergerak (atas), dan dalam keadaan diam (bawah). Koperski, The Physics of Theism, 183

Ketika piston bergerak maju mundur, maka roda kereta api akan berputar berlawanan dengan jarum jam sehingga kereta bergerak

\footnotetext{
${ }^{46}$ Koperski, The Physics of Theism, 186. Penekanan oleh penulis.

${ }^{47}$ Dua contoh fenomena ini diambil dari Mark Wilson, "Critical Notice: John Earman's A Primer on Determinism," Philosophy of Science 56, no. 3 (1989): 509.
}

maju (lihat gambar 1 bagian atas). Pergerakan dari piston tersebut menentukan pergerakan dari roda kereta. Namun, apa yang terjadi ketika roda dalam keadaan berhenti sedemikian rupa sehingga rel penghubung antara piston dan roda dalam keadaan horisontal seperti yang tampak pada gambar 1 bagian bawah? Ketika piston mulai bergerak ke kanan ke arah roda, maka ke arah manakah roda tersebut akan berputar? Apakah berlawanan dengan jarum jam atau searah dengan jarum jam? Roda tersebut pasti akan berputar sesuai dengan hukum fisika klasik, tetapi ke arah manakah roda itu akan berputar tidak ditentukan oleh hukum tersebut. Ada lebih dari satu akibat yang mungkin terjadi dari satu penyebab tunggal. Hasil yang terjadi bersifat indeterministik.

Contoh lainnya adalah sepotong besi tipis yang kedua ujungnya memiliki penopang berbentuk segitiga, dan ditegakkan secara vertikal, seperti yang tampak pada gambar:

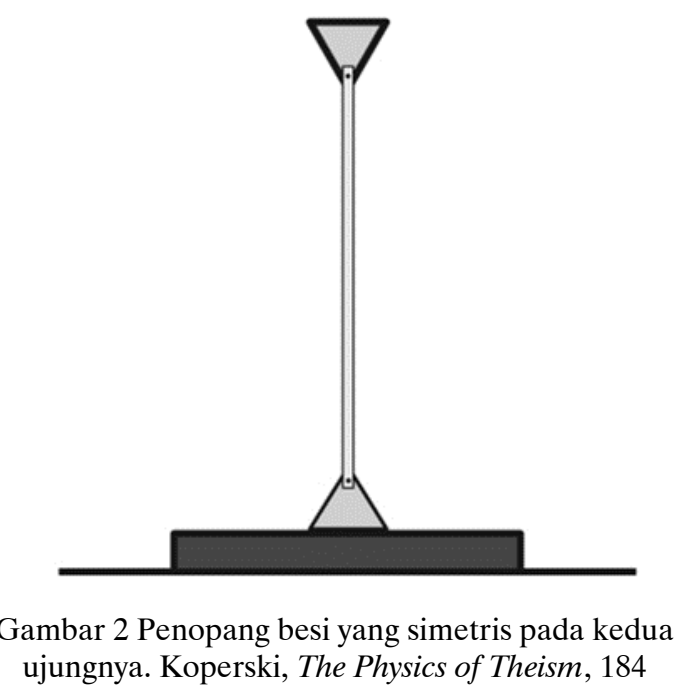

Anggap saja eksperimen ini dilakukan di dalam ruang hampa udara dan bebas dari getaran luar. Di atas besi tersebut kemudian terus-menerus diletakkan beban yang seimbang, yang semakin lama semakin banyak. Pada saat beban yang ditambahkan itu semakin berat, maka besi yang tipis tersebut akan melengkung. Ke arah manakah besi tersebut akan melengkung, apakah ke kanan atau ke 
kiri, ke depan atau ke belakang, atau diagonal? Menurut hukum fisika klasik, besi yang kelebihan beban tersebut pasti akan melengkung. Tetapi, hukum tersebut tidak cukup untuk menentukan ke arah manakah besi itu akan melengkung. Dengan demikian, hasilnya bersifat indeterministik, karena untuk satu penyebab tunggal ada lebih dari satu kemungkinan akibat yang dihasilkan.

Ilustrasi besi penopang dan roda kereta api di atas cukup untuk memperlihatkan bahwa jika determinisme memiliki pengertian setiap peristiwa yang terjadi di dalam dunia ini sudah ditetapkan oleh hukum-hukum alam, maka fisika klasik sekalipun (yang diasumsikan memiliki paradigma determinisme secara fisik) tidak dapat dianggap deterministik sepenuhnya. Hal ini pula yang juga telah disadari oleh the International Union of Theoretical and Applied Mechanics, yang menyampaikan permintaan maaf secara publik pada tahun 1986, sebagai berikut:

We collectively wish to apologize for having misled the general educated public by spreading ideas about the determinism of systems satisfying Newton's law of motion that, after 1960, were proved to be incorrect ... Modern theories of dynamical systems have clearly demonstrated the unexpected fact that systems governed by the equations of Newtonian dynamics do not necessarily exhibit the 'predictability' property. ${ }^{48}$

Dengan demikian, pengertian determinisme tidak bisa lagi sesederhana atau sebatas yang didefinisikan oleh filsuf Belanda bernama Baruch Spinoza (1632-1677): "Nothing happens in nature which does not follow from her laws." 49

${ }^{48}$ James Lighthill, "The Recently Recognized Failure of Predictability in Newtonian Dynamics," dalam Proceedings of the Royal Society A: Mathematical, Physical and Engineering Sciences 407 (1986): 35, 38.

${ }^{49}$ Theologico-Political Treatise Bk 2 VI:21, seperti yang dikutip oleh Koperski, The Physics of Theism, 182183.
Kembali kepada paradigma dari mekanika klasik Newton, determinisme hanya bisa terjadi di dalam sebuah sistem yang tertutup atau terisolasi dari dunia luar. Namun, adanya fenomena-fenomena seperti yang sudah dijelaskan di atas, yang memperlihatkan adanya probabilitas dan kejadian yang indeterministik, justru membuktikan bahwa alam semesta ini sesungguhnya tidak bersifat tertutup secara kausal. Pada kenyataannya, sebuah sistem terisolasi hanyalah idealisme belaka, karena di dalam dunia yang dipengaruhi oleh gravitasi dan elektromagnet, setiap bagian kecil (unsur) dari materi mempengaruhi bagian-bagian lainnya. ${ }^{50}$ Hukum alam hanya menjelaskan cara kerja tatanan alam ini ketika dibiarkan berjalan sendiri tanpa interferensi (campur tangan dari luar). Namun, ketika terjadi kondisi luar yang menyela masuk ke dalam tatanan alam tersebut, hukum alam itu akan memberi ruang bagi interferensi tersebut. Misalnya, ketika seseorang dengan cekatan menangkap sebongkah batu yang jatuh dari ketinggian tertentu sebelum batu itu melukai kepala seseorang, orang tersebut tidak dapat dikatakan sedang mengintervensi hukum gravitasi. Demikian pula Allah dapat mengubah keadaan-keadaan yang di dalamnya hukum-hukum alam bekerja (termasuk hukum yang deterministik), tanpa melanggarnya.

Semua kajian di atas memperlihatkan bahwa fisika kuantum sebenarnya tidak meruntuhkan determinisme fisika klasik seperti yang diasumsikan oleh DAP yang menganut konsep tindakan ilahi nonintervensionis. Fisika klasik maupun fisika kuantum sebenarnya memperlihatkan bahwa alam semesta selalu terbuka, tidak pernah tertutup secara kausal, bagi tindakan ilahi. Mengenai perubahan paradigma terhadap makna determinisme ini, Koperski menyimpulkannya sebagai berikut:

Determinism in physics is more nuanced

${ }^{50}$ Koperski, The Physics of Theism, 185. 
that conventional wisdom might suggest. Spinoza's view ... is oversimplified. Newton himself would not have endorsed it. In fact, determinism isn't the issue at all, or at least it should not be. Noninterventionist have misidentified the enemy. ${ }^{51}$

Dengan demikian, para sarjana DAP telah salah memandang determinisme fisika klasik sebagai "musuh" bagi tindakan ilahi. Persoalan yang sesungguhnya bagi tindakan ilahi khusus adalah asumsi yang telah melekat kuat di dalam pikiran para sarjana DAP bahwa sains mengharuskan alam semesta ini bersifat tertutup secara kausal.

Dari seluruh pembahasan di bagian ini, dapat disimpulkan dua hal. Pertama, alam semesta sesungguhnya bersifat terbuka dan sains tidak harus mendalilkan bahwa alam semesta ini tertutup secara kausal. Dengan demikian, hukum-hukum alam tidak pernah menjadi penghalang bagi Allah untuk bertindak secara khusus di dalam dunia ini. Howard mengatakan bahwa hukum-hukum alam bukanlah entitas yang berdiri sendiri di luar Allah, melainkan deskripsi dari karya Allah di dalam penciptaan dan providensi:

Natural law cannot conscribe God's action because in fact natural law is nothing other than an imperfect scientific description of God's habits of providence. The law of causality does not stand outside God as a force with which he must reckon. Rather, the law describes the work of God in creation. ${ }^{52}$

Dengan demikian, tindakan ilahi khusus tidak bisa dipahami sebagai intervensi (dalam arti melanggar hukum-hukum alam seperti yang diasumsikan oleh para sarjana DAP) dan juga tidak bermasalah sama sekali dengan sains. Elliot Sober juga mengungkapkan hal ini demikian:

But what does 'divine intervention' mean?

\footnotetext{
${ }^{51}$ Koperski, The Physics of Theism, 184.

${ }^{52}$ Howard, "The Copenhagen Interpretation," 118.
}

What I want to consider ... is the view that God supplements what happens in the evolutionary process without violating any laws. An intervention, as I'll understand the term, is a cause; it can trigger an event or sustain a process. Physicians do both when they intervene in the lives of their patients. Physician intervention does not entail any breakage in the laws of nature; neither does God's. ${ }^{53}$

Kedua, para teolog atau sarjana DAP telah salah menilai hukum-hukum alam sebagai pembatas bagi tindakan ilahi. Setiap teori tindakan ilahi khusus yang berusaha mencari indeterminisme secara ontologis di dalam keteraturan alam dibangun dari kesalahan asumsi bahwa determinisme secara kausal menjadi ancaman bagi Allah untuk bertindak di dalam dunia ini. Faktor-faktor penyebab di dalam proses-proses natural mesti dipandang sebagai karya ciptaan Allah sendiri. Hukum-hukum alam dan keteraturan-keteraturan di dalamnya adalah deskripsi dari perbuatan Allah sendiri di dalam karya pemeliharaan-Nya atas dunia natural..$^{54}$

Di atas telah dibahas dan dikaji tiga asumsi filosofis dari DAP yang mencetuskan NIODA, yaitu: (1) indeterminisme secara ontologis, yang berasal dari asumsi bahwa tindakan ilahi harus bersifat (2) nonintervensionis, karena memahami (3) hukum alam yang bersifat ontologis dan preskriptif. Namun, jika ditelusuri lebih dalam lagi, akar dari ketiga asumsi ini adalah pemahaman bahwa tindakan ilahi khusus bersifat inkompatibel dengan hukum-hukum alam yang menjadi penyebab natural dari segala sesuatu yang terjadi di alam semesta ini.

${ }^{53}$ Elliott Sober, "Why Methodological Naturalism?" dalam Biological Evolution: Facts and Theories: A Critical Appraisal 150 Years After the Origin of Species, ed. G. Auletta, M. Leclerc, dan R. A. Martinez (Roma: Gregorian and Biblical Press, 2011), 362. Penekanan oleh penulis.

${ }^{54}$ Vern S. Poythress, "Why Scientist Must Believe in God: Divine Attributes of Scientific Law," Journal of the Evangelical Theological Society 46, no. 1 (2003): 112. 


\section{Inkompatibilisme}

Para sarjana DAP secara umum menganut konsep tindakan ilahi yang inkompatibilis, yaitu bahwa Allah dan hukum-hukum alam tidak mungkin sama-sama bertanggung jawab sebagai penyebab atas satu peristiwa yang sama. Penganut inkompatibilisme akan bersikeras menyatakan, "in order for God to act, something in the natural order has to give away." 55 Pendekatan inkompatibilis ini telah menjadi asumsi utama dari konsep-konsep tindakan ilahi yang mencari titik temu kausal dari fenomena-fenomena alam semesta di mana sains masih belum memiliki bukti-bukti yang cukup pasti untuk menentukan hukumhukum alam yang mengaturnya (underdetermined). Dengan demikian kaum inkompatibilis harus menemukan celah-celah di dalam rantai kausal hukum-hukum alam di mana Allah dapat bekerja sebagai tambahan terhadap mekanisme fisik yang ada.

Dari semua pembahasan dan kajian di bagian ini terlihat bahwa konsep tindakan ilahi yang menonjol dalam dekade terakhir (diwakili oleh DAP dan NIODA-nya) telah didominasi oleh asumsi filosofis inkompatibilis dan nonintervensionis yang menganggap hukum alam bersifat ontologis-preskriptif dan tindakan Allah harus dicari dalam fenomena alam yang bersifat indeterministik secara ontologis. Konsep tindakan ilahi dengan asumsi-asumsi filosofis seperti ini cenderung menjadikan sains sebagai wasit terakhir yang menentukan di mana dan bagaimana Allah dapat bertindak di dalam alam semesta; dan dengan kata lain, teologi pun harus tunduk di bawah pengetahuan saintifik yang berkembang saat ini. Dengan demikian, apa implikasi teologis dari konsep tindakan ilahi yang dibangun berdasarkan teori sains tertentu?

Model tindakan ilahi yang diusulkan DAP pada akhirnya cenderung menyejajarkan tindakan ilahi tersebut dengan penyebab-

${ }^{55}$ Smedes, "Beyond Barbour or Back to Basics," 246. penyebab natural lainnya. Otto Herman Pesch berargumen bahwa jika Allah menjadi penyebab tersembunyi dari peristiwa kuantum, Allah hanya menjadi "bagian" dari dunia ini sebagai salah satu penyebab di samping penyebab-penyebab natural lainnya: "To think of God as a hidden secret in the indeter-minateness of natural processes is to think of him as a factor in the world and so as part of the world." ${ }^{56}$ Lebih lanjut, Dodds mengatakan bahwa konsep tindakan ilahi yang demikian telah memperlakukan Allah sebagai penyebab univokal bersama dengan penyebab-penyebab natural lainnya:

One overarching criticism applies to all approaches to divine action that directly employ interpretations of the theories of contemporary science. Despite their occasional protestations to the contrary, they all tend to treat God as a univocal cause alongside natural causes. ${ }^{57}$

Dodds menggunakan istilah penyebab univokal (univocal cause) dalam pengertian yang luas untuk menunjuk kepada sebuah penyebab efisien yang berada di dalam ordo yang sama dengan penyebab efisien lainnya sehingga mereka dapat bekerja sama untuk menghasilkan dampak tertentu. ${ }^{58}$ Pada saat dua penyebab yang demikian bertindak bersama-sama, tanpa dapat dihindari, kausalitas yang satu mengintervensi kausalitas lainnya di dalam pengertian jika yang satu lebih berkontribusi terhadap dampak yang dihasilkan maka yang lainnya menjadi kurang berkontribusi. Misalnya, ketika dua orang mengangkat sebuah meja, semakin besar berat yang ditanggung satu orang, semakin berkurang berat yang harus ditanggung orang

${ }^{56}$ Otto Herman Pesch, "Theologische Uberlegungen zur 'Vorsehung Gottes' im Blick auf gegenwartige naturund humanwissenswchaftliche Erkenntnisse," dalam Christlicher Glaube in Moderner Gesellschaft, ed. Franz Bockle et al., (Freiburg: Herder, 1982), 4.92, seperti dikutip dalam Dodds, Unlocking Divine Action, 143.

${ }^{57}$ Dodds, Unlocking Divine Action, 153.

${ }^{58}$ Ibid., 153, 266. 
lainnya. Yang perlu diperhatikan di sini adalah Dodds menggunakan istilah univokal bukan dalam pengertian spesies yang sama, tetapi dalam tingkatan kausalitas yang sama. De-ngan pemahaman univokal yang seperti ini maka dapat disimpulkan model tindakan ilahi yang dibangun DAP berdasarkan penafsiran teori sains tertentu telah mereduksi Allah menjadi sama tingkatannya dengan penyebab-penyebab natural lainnya.

Dengan mencermati asumsi-asumsi filosofis di balik NIODA maka dapat disimpulkan bahwa DAP, dengan ambisinya untuk membangun sebuah konsep tindakan ilahi yang kredibel secara saintifik, tidak dapat memperlihatkan teologi tindakan ilahi yang adekuat dan memadai. Lokus dan ruang gerak tindakan Allah di dalam alam semesta ini cenderung menjadi sangat kecil, tidak terlihat dan bahkan tidak mampu untuk memperlihatkan dampaknya yang signifikan. Jika demikian adanya, apakah NIODA (dan secara khusus QM-NIODA) sanggup memperlihatkan tindakan Allah yang memadai untuk melaksanakan dan menggenapi apa yang dikehendaki-Nya secara efektif? Tampaknya tidak. Nicholas Saunders meragukan bahwa tindakan Allah dalam QM-NIODA dapat menghasilkan dampak makroskopis yang memadai. Menurutnya, untuk melakukan suatu hasil yang signifikan pada tingkatan makroskopis, Allah harus mengendalikan proses kuantum dalam jumlah yang sangat besar dan membutuhkan waktu yang sangat lama. Dia memberi contoh misalnya untuk memunahkan dinosaurus dengan sebuah asteroid, Allah membutuhkan waktu sekitar tiga juta tahun untuk menggerakkan asteroid tersebut. ${ }^{59}$ Oleh sebab itu, dibutuhkan suatu upaya untuk membangun konsep tindakan ilahi yang tidak hanya kredibel secara saintifik namun juga memadai secara teologis.

\footnotetext{
${ }^{59}$ Nicholas T. Saunders, "Does God Cheat at Dice? Divine Action and Quantum Possibilities," Zygon 35, no. 3 (2000): 540.
}

\section{SEBUAH USULAN KONSEP TINDAKAN ILAHI KHUSUS YANG MEMADAI}

Werner Heisenberg (1901-1976), fisikawan Jerman yang memenangkan Nobel untuk risetnya di bidang mekanika kuantum, pernah berkata, "Tegukan pertama dari gelas sains natural akan mengubahmu menjadi seorang ateis, namun di dasar gelas, Allah sedang menunggumu." ${ }^{60}$ Kalimat Heisenberg ini mengingatkan kembali bahwa titik tolak untuk membangun sebuah konsep tindakan ilahi yang memadai secara teologis tidak bisa dilepaskan dari apa yang Allah katakan sendiri di dalam Alkitab tentang relasi-Nya dengan dunia yang diciptakan-Nya. Data-data Alkitab memperlihatkan bahwa Allah bukanlah Allah deisme yang lepas tangan membiarkan dunia ciptaan-Nya berjalan sendiri, atau sebaliknya Dia juga bukan Allah panteisme yang melebur menjadi satu dengan ciptaan-Nya. Allah yang dinyatakan dalam Alkitab adalah Allah transenden yang dapat terlibat secara imanen di dalam dunia ciptaan-Nya namun pada saat yang sama Ia tetap transenden dan tidak menjadi sama dengan ciptaan-Nya. Allah yang transenden itu dapat berelasi dan terlibat secara imanen dengan dunia ciptaan-Nya melalui hubungan yang bersifat kovenantal. Kunci untuk memahami hal ini adalah natur Allah yang trinitarian.

\section{Relasi Allah dengan Dunia Ciptaan yang bersifat Trinitarian dan Kovenantal}

Ikatan perjanjian kovenan ${ }^{61}$ antara Allah dengan ciptaan-Nya dimulai pada saat Ia

\footnotetext{
${ }^{60}$ Kalimat yang secara umum diasosiasikan kepada Heisenberg ini dikutip dari tulisan Ulrich Hildebrand, "Das Universum - Hinweis auf Gott?", dalam Ethos. Die Zeitschrift für die ganze Familie (1988), 10.

${ }^{61}$ Pengertian "perjanjian" (kovenan) di sini adalah kesepakatan serius yang diikat oleh sumpah yang dibuat di dalam relasi formal antara Allah dan manusia dengan segala kewajiban dan konsekuensi yang mengikutinya jika menaati atau tidak menaatinya. Penjelasan lebih rinci dapat dilihat dalam David VanDrunen, Divine Covenants and Moral Order: A Biblical Theology of Natural Law (Grand Rapids: Eerdmans, 2014), 15-16.
} 
menciptakan dunia ini. ${ }^{62}$ Penciptaan alam semesta adalah karya Allah Tritunggal seperti yang dicatat dalam Kejadian 1:1-3, 2628. Jika di sini Musa mengatakan kepada bangsa Israel bahwa Allah menciptakan alam semesta melalui firman-Nya, maka rasul Yohanes mengatakan bahwa Allah menciptakan alam semesta melalui Yesus Kristus, Sang Firman yang menjadi manusia (Yoh. 1:1-14). Allah yang dahulu mengikat perjanjian dengan umat-Nya, Israel, sekarang telah berinkarnasi di dalam Yesus Kristus, yang menyatakan kemuliaan Allah kepada seluruh dunia. Dari kedua perikop ini dapat disimpulkan dua hal: (1) ikatan perjanjian anugerah antara Allah dan umat-Nya tidak bisa dilepaskan dari hubungan Allah dengan seluruh ciptaan-Nya; dan (2) Yesus Kristus menjadi Perantara di dalam perjanjian Allah dengan ciptaan-Nya. ${ }^{63}$

Di manakah peran Roh Kudus, Pribadi ketiga dari Tritunggal, dalam karya penciptaan dan pemeliharaan dunia ini? Christopher J.H. Wright mengatakan bahwa Roh Kudus adalah "The Creating Spirit" yang menciptakan, menopang, memperbarui dunia ini, dan bahkan berperan di dalam penebusan seluruh ciptaan menjadi ciptaan baru. ${ }^{64}$ Pertama, Roh Kudus menjadikan segala sesua-

\footnotetext{
${ }^{62}$ VanDrunen, Divine Covenants, $80-83$. Ia berargumen bahwa meskipun di dalam Kejadian 1-2 tidak terdapat kata "perjanjian" (Ibr. (בְּרִית) namun, ada 4 alasan untuk melihat kisah penciptaan sebagai sebuah perjanjian: (1) Hosea 6:7 menyebut relasi Allah yang semula dengan Adam sebelum kejatuhan dengan istilah perjanjian; (2) penggambaran Allah sebagai Raja mengindikasikan pembacaan secara kovenantal; (3) adanya kesamaan yang luar biasa antara Kejadian 1-2 dan perjanjian Allah yang belakangan dengan Nuh dan Israel mengindikasikan pembacaan kisah penciptaan dalam terang kovenan; dan (4) adanya ciri-ciri perjanjian seperti Allah membangun relasi yang formal dengan manusia menyampaikan kewajiban yang harus dipenuhi dan ditaati oleh manusia beserta dengan konsekuensinya jika melanggar.

${ }^{63}$ Tim Morris dan Don Petcher, Science and Grace: God's Reign in the Natural Sciences (Wheaton: Crossway, 2006), 98.

${ }^{64}$ Christopher J.H. Wright, Knowing the Holy Spirit Through the Old Testament (Downers Grove: InterVarsity, 2006), bab 1.
}

tu. Mazmur 33:6 berkata, "Oleh firman TUHAN langit telah dijadikan, oleh nafas dari mulut-Nya segala tentaranya." Wright meyakini bahwa nafas Allah di ayat ini terkait erat dengan Roh Kudus. ${ }^{65}$ Elihu, sahabat Ayub, juga berkata, "Roh Allah telah membuat aku, dan nafas Yang Mahakuasa membuat aku hidup" (Ayb. 33:4). Kedua, Roh Kudus menjaga selama penciptaan berlangsung. Dalam Kejadian 1:2 dikatakan, "Roh Allah melayang-layang di atas permukaan air." Wright melihat kata "melayang-layang" di sini juga digunakan dalam Ulangan 32:11 sebagai metafora Allah menjaga dan menyertai umat-Nya. ${ }^{66}$ Ketiga, Roh Kudus menopang seluruh ciptaan. Ayub 34:14-15 menyatakan, "Jikalau Ia menarik kembali RohNya, dan mengembalikan nafas-Nya padaNya, maka binasalah bersama-sama segala yang hidup, dan kembalilah manusia kepada debu." Keempat, Roh Kudus juga memperbarui seluruh ciptaan. Pemazmur berkata, "Apabila Engkau mengirim Roh-Mu, mereka tercipta, dan Engkau membaharui muka bumi” (Mzm. 104:30). Ayat-ayat Alkitab lainnya yang berbicara mengenai peran Roh Kudus sebagai pemberi hidup yang menopang segala ciptaan adalah Yesaya 32:15, Yohanes 6:63 dan Roma 8:2, 6, 11. Dari semua data-data Alkitab ini dapat disimpulkan bahwa Roh Kudus bukan hanya sumber kehidupan rohani tetapi juga sumber kehidupan jasmani. Dia tidak hanya berperan dalam karya keselamatan tetapi juga dalam penciptaan dan pemeliharaan dunia ini. ${ }^{67}$

Relasi perjanjian antara Allah dengan dunia ciptaan-Nya tampak lebih jelas di dalam ikatan perjanjian antara Allah dengan Nuh (Kej. 8:20-9:17). Dalam perikop ini dikatakan Allah berfirman dalam hati-Nya (8:21) atau, dengan kata lain, berjanji kepada diri-

${ }^{65}$ Wright, Knowing the Holy Spirit, 15.

${ }^{66}$ Ibid., 14.

${ }^{67} \mathrm{John}$ Calvin berkata, "For it is the Spirit who, everywhere diffused, sustains all things, causes them to grow, and quickens them in heaven and in earth" (Instit., terj. Battles, 1.13.14). 
Nya sendiri, untuk dua hal. Pertama, Allah menyatakan anugerah-Nya kepada segala makhluk dengan berjanji tidak akan membinasakan bumi ini lagi seperti yang telah Ia lakukan (8:21). Kedua, Allah juga memberi kepastian bahwa segala sesuatu yang terjadi di dalam alam ini akan berlangsung secara teratur dan konstan: "Selama bumi masih ada, takkan berhenti-henti musim menabur dan menuai, dingin dan panas, kemarau dan hujan, siang dan malam" (8:22). Di dalam kovenan ini tersirat bahwa Allah mengatur segala proses dan perilaku di dalam dunia natural, seperti matahari, bulan, air, hewan, dan tumbuhan, melalui hukum alam. ${ }^{68}$

Relasi kovenan Allah dengan ciptaan-Nya menjadi makin jelas lagi dinyatakan di dalam nubuat Yeremia mengenai Perjanjian Baru (Yer. 31:31-37). Dalam ayat 35-37 terlihat keterjalinan yang kuat antara perjanjian Allah dengan umat-Nya dan perjanjian Allah dengan alam ciptaan-Nya. Di sini Allah menjamin kesetiaan-Nya menggenapi perjanjian baru terhadap umat-Nya dengan menunjukkan ketetapan-ketetapan-Nya yang mengatur segala proses natural di dalam dunia ini. Sepasti matahari selalu menerangi siang dan bulan serta bintang menerangi malam, maka demikian pula sepasti itulah Allah tidak akan menolak umat-Nya dan akan mengampuni dosa-dosa mereka. Digunakannya kata "menetapkan" dan "ketetapan"69 di ayat 35-36 mengindikasikan dua hal: (1) keberadaan segala sesuatu di dalam dunia ciptaan bergantung penuh kepada karya pemeliharaan Allah yang terusmenerus menopang ciptaan-Nya, dan (2) Allah menata ciptaan-Nya agar beroperasi secara teratur melalui hukum-hukum alam. Bahkan di pasal 33, Allah menegaskan lebih kuat lagi hukum-hukum alam ini sebagai sebuah perjanjian ketika Dia menyebutkan

${ }^{68}$ Morris dan Petcher, Science and Grace, 102.

${ }^{69} \mathrm{Di}$ sini digunakan kata yang akarnya adalah NRSV menerjemahkan dengan fixed order, dan NLT menerjemahkannya di ayat 36 sebagai laws of nature.
"perjanjian-Ku dengan siang dan perjanjian$\mathrm{Ku}$ dengan malam" $(33: 20,25)$ serta "atur$\mathrm{an}^{70}$ langit dan bumi" (33:25) yang ditetapkan-Nya pada waktu penciptaan mulamula. ${ }^{71}$ Hukum-hukum alam ini dengan taat akan melaksanakan dan menggenapi tujuan yang Allah kehendaki. Ayat-ayat lainnya yang menyatakan kebesaran dan kedaulatan Allah di dalam menciptakan dan mengatur alam semesta adalah Ayub 38:4-7, 31-35; Yeremia 5:22, 24; 10:12-16; 51:15-19; dan Yesaya 40:12, 26; 42:5; 44:24; 45:7, 18.

Jika melihat lebih jauh catatan Alkitab mengenai perjanjian antara Allah dengan dunia ciptaan maka terlihat ciri kesamaannya dengan perjanjian anugerah keselamatan, yaitu diperantarai oleh Firman Allah. Pemazmur mengatakan, "Yang Mahakuasa, TUHAN Allah, berfirman dan memanggil bumi, dari terbitnya matahari sampai kepada terbenamnya" (Mzm. 50:1). Bahkan Allah sendiri menegaskan ketaatan ciptaan kepada hukumhukum-Nya terkait erat dengan bagaimana firman-Nya taat melaksanakan dan menggenapi kehendak-Nya (Yes. 55:10-12). Di dalam Perjanjian Baru dikatakan bahwa Yesus Kristus, Sang Firman Allah yang menjadi manusia itu, tidak hanya menjadi perantara di dalam perjanjian anugerah Allah dengan umat tebusan-Nya namun juga perantara di dalam perjanjian Allah dengan seluruh ciptaan. ${ }^{72}$ Allah menciptakan segala sesuatu di dalam Kristus, dan, melalui kematian dan kebangkitan-Nya, menempatkan Dia dalam posisi tertinggi sebagai Kepala dari segala sesuatu yang ada dan yang telah ditaklukkan di bawah kaki-Nya (1Kor. 15:27; Kol. 1:1320; Ef. 1:20-22; Ibr. 2:8). Kristus menopang segala yang ada di dalam dunia ciptaan Allah dengan otoritas firman-Nya yang penuh

${ }^{70}$ Di sini digunakan kata dengan akar yang sama seperti 31:35-36 yaitu

${ }^{71}$ VanDrunen, Divine Covenants and Moral Order, 81. Lihat juga J. Richard Middleton, The Liberating Image: The Imago Dei in Genesis 1 (Grand Rapids: Brazos, 2005), 68.

${ }^{72}$ Morris dan Petcher, Science and Grace, 105. 
kuasa (Ibr. 1:3) untuk membawa seluruh ciptaan ini menggenapi tujuan Allah yang tertinggi yaitu menegakkan kerajaan-Nya. ${ }^{73}$

Dari seluruh penguraian data Alkitab di atas dapat disimpulkan bahwa hubungan antara Allah Pencipta dengan dunia ciptaan-Nya bersifat trinitarian dan kovenantal. Allah Bapa menciptakan dunia ini melalui Allah Anak yang menopang ciptaan-Nya melalui kehadiran Allah Roh Kudus, yang senantiasa menata, memberi hidup dan memperbarui seluruh ciptaan. Herman Bavinck menyuarakan keindahan pemahaman ini dengan berkata:

The outgoing works of God are indivisible though it is appropriate to distinguish an economy of tasks in the Godhead so that the Father is spoken of as the first cause, the Son as the one by whom all things are created, and the Holy Spirit as the immanent cause of life and movement in the universe. ${ }^{74}$

Dengan pemahaman seperti di atas maka hubungan Allah yang transenden dengan dunia ciptaan yang imanen tidak menjadi berat sebelah kepada pandangan Allah deisme yang membiarkan dunia berjalan sendiri secara mekanis maupun Allah panteisme (atau panenteisme) yang ikut berubah dan berkembang bersama ciptaan-Nya. Berbeda dengan kedua pandangan di atas, pandangan Alkitab mempertahankan dualitas Allah Pencipta yang transenden dan dunia ciptaan yang imanen. Dualitas Penciptaciptaan yang dimaksud di sini adalah dualitas yang tidak simetris antara keberadaan Allah yang, secara absolut, tidak bergantung kepada apapun, dan keberadaan ciptaan yang bergantung penuh kepada Allah. Allah yang transenden itu dapat tetap berelasi dan

\footnotetext{
${ }^{73}$ Morris dan Petcher, Science and Grace, 106.

${ }^{74}$ Herman Bavinck, In the Beginning: Foundation of Creation Theology, ed. John Bolt, terj. John Vriend (Grand Rapids: Baker, 1999), 23, seperti yang dikutip oleh Morris dan Petcher, Science and Grace, 107.
}

bertindak di dalam dunia yang imanen tanpa kehilangan transendensi-Nya dan menjadi sama dengan dunia ini. Semuanya ini dimungkinkan oleh konsep Allah yang trinitarian, yang berelasi dengan dunia menurut kesetiaan-Nya kepada perjanjian yang telah dibuat-Nya (kovenantal). Allah Tritunggal adalah transenden dalam peran-Nya sebagai Bapa, namun juga imanen dalam karya Roh Kudus, dengan Yesus Kristus sebagai Perantara.

Pandangan Alkitab juga memperlihatkan bahwa dunia ciptaan tidak bersifat otonom dari Allah, dan juga tidak berjalan secara mekanistik-deterministik di dalam kendali hukum-hukum alam yang bersifat ontologis. Hukum-hukum alam lebih tepat dilihat sebagai ekspresi dari ketetapan dan kesetiaan Allah Pencipta yang berdaulat dan menopang keteraturan di alam semesta ini. Namun demikian, Allah memiliki tujuan teleologis dan eskatologis yang lebih tinggi dari yang sanggup diekspresikan oleh hukum alam. Hukum-hukum alam ini tunduk untuk melayani tujuan dan rencana Allah yang lebih tinggi tersebut. Implikasi dari hal ini ada dua. Pertama, kita akan menemukan adanya ketidaklengkapan di dalam ciptaan karena Allah masih sedang terus bertindak di dalam dunia ini untuk menggenapi rencana-Nya yang kekal. ${ }^{75}$ Ketidaklengkapan ini tidak bertentangan dengan bagaimana Allah telah menilai dengan baik dunia yang diciptakanNya ini. Ketidaklengkapan ini juga tidak bermaksud mengatakan ada yang tidak lengkap pada diri Allah atau bahwa Dia kurang mahakuasa. Ketidaklengkapan ini dapat dimengerti dalam analogi dengan hukum Taurat. Sama seperti hukum Taurat hanyalah bayang-bayang dari realita Perjanjian Baru yang sesungguhnya dinyatakan di dalam Kristus ${ }^{76}$ maka hukum-hukum alam juga bersifat tidak lengkap dan hanya memperlihat-

\footnotetext{
${ }^{75}$ Morris dan Petcher, Science and Grace, 149.

${ }^{76} \mathrm{Hal}$ ini dinyatakan oleh rasul Paulus dalam Kolose 2:17 dan penulis surat Ibrani dalam Ibrani 10:1.
} 
kan bayang-bayang dari realita konsumasi yang sesungguhnya. Implikasi yang pertama memimpin pada implikasi yang kedua, yaitu tindakan-tindakan Allah di dalam dunia ciptaan tidak terbatas hanya melalui hukumhukum alam namun dapat melampaui hukum tersebut. Allah, di dalam kedaulatanNya dan kesetiaan-Nya, akan terus-menerus bertindak untuk mengarahkan dunia ini sampai kepada konsumasi dari tujuan-Nya yang eskatologis, yaitu penciptaan baru yang mempersatukan segala sesuatu di dalam Kristus. $^{77}$

\section{Konsep Tindakan Ilahi Khusus yang Trinitarian, Kovenantal dan Saintifik}

Dari kajian terhadap DAP dapat disimpulkan bahwa NIODA yang diusulkan DAP dapat dianggap kredibel secara saintifik namun tidak memadai secara teologis. ${ }^{78}$ Karena itu, upaya membangun sebuah konsep tindakan ilahi khusus yang memadai secara teologis harus mendekonstruksi semua asumsi filosofis yang mendominasi DAP dan merekonstruksi asumsi-asumsi baru yang didasari pada teologi penciptaan mengenai relasi Allah dengan dunia ciptaan yang bersifat trinitarian dan kovenantal. Hasilnya adalah sebuah konsep tindakan ilahi khusus yang memadai secara teologis dan saintifik dengan tiga ciri-ciri berikut ini.

Pertama, sebuah konsep tindakan ilahi khusus yang memadai secara teologis dan saintifik akan melihat hubungan antara Allah dengan dunia ciptaan bersifat kompatibilis-

\footnotetext{
${ }^{77}$ Morris dan Petcher, Science and Grace, 133.

${ }^{78}$ Cross dalam disertasinya secara khusus berfokus untuk mengevaluasi perspektif teologis dari DAP yang diprakarsai oleh VO/CTNS. Dalam penyelidikannya ia menyimpulkan bahwa teori-teori tindakan ilahi yang diusulkan DAP cenderung mengesampingkan perspektif tradisi teologi yang injili maupun ortodoks. Penjabaran lebih rinci mengenai hal ini dapat dilihat dalam "Perspectives on Divine Action: Reflections on the Theological Legitimacy of Approaches to Divine Action in the V.O./ C.T.N.S. Series 'Scientific Perspectives on Divine Action"” (disertasi, University of Oxford, 2017), bab 1.
}

tik secara theo-physical, artinya kebebasan Allah untuk bertindak bersifat kompatibel dengan rantai kausalitas di dalam dunia natural. ${ }^{79}$ Sebagai Pencipta, Allah adalah sumber atas segala sesuatu yang ada di alam semesta ini, termasuk kebenaran yang sejati mengenai dunia natural. Oleh sebab itu, tindakan-Nya untuk memelihara keteraturan alam semesta, serta mengarahkan jalannya sejarah dunia tidak mungkin melanggar proses-proses natural di dalam dunia yang diciptakan-Nya. Jika Allah adalah Pencipta alam semesta ini, maka tindakan-Nya di dalam dunia bukanlah masalah yang harus diselesaikan, melainkan sebuah realitas yang harus diakui, diterima dan menjadi fondasi dari seluruh pengetahuan mengenai alam ini. ${ }^{80}$ Dengan demikian, yang harus dijelaskan dan dipertanggungjawabkan bukanlah tindakan Allah, melainkan keberadaan sains natural di dalam dunia ciptaan ini.

Ketika teologi penciptaan memberikan asumsi baru bahwa dualitas hubungan Penciptaciptaan bersifat trinitarian, kovenantal dan kompatibel secara theo-physical maka hal ini menjadi pola dasar untuk memahami realitas. Dengan demikian, tindakan Allah di dalam dunia tidak lagi dilihat sebagai sebuah masalah. Dualitas ini memperlihatkan bahwa masalah sesungguhnya di dalam perdebatan antara sains dan teologi mengenai tindakan ilahi adalah permasalahan ini tidak ditempatkan dalam kerangka yang benar.

\footnotetext{
${ }^{79}$ Menurut para sarjana DAP, ada tiga jenis inkompatibilisme/kompatibilisme yang berhubungan dengan sebuah konsep tindakan ilahi, yaitu anthropo-physical, anthropo-theological, dan theo-physical. Anthropo-physical berkaitan dengan hubungan antara kebebasan manusia dengan determinisme dunia fisik, anthropo-theological berkaitan dengan hubungan antara kebebasan manusia dengan determinisme ilahi, sedangkan theo-physical berkaitan dengan hubungan antara kebebasan Allah dengan determinisme dunia fisik. Dari antara ketiganya, yang menjadi perhatian utama DAP adalah hubungan theophysical. Penjelasan lebih rinci mengenai hal ini dapat dilihat dalam Wildman, "The Divine Action Project," 39.

${ }^{80}$ Lydia Jaeger, "Against Physicalism-plus-God: How Creation Accounts for Divine Action in the World," Faith and Philosophy 29, no. 3 (2012): 304.
} 
Karena dunia ini secara total bergantung penuh kepada Allah Pencipta, maka keberadaannya bisa terus berlangsung hanya jika Allah terus-menerus menopangnya. Dengan demikian, dunia natural justru tidak menjadi penghambat bagi tindakan ilahi, sebaliknya malah mengandalkan Allah yang secara aktif terus-menerus terlibat di dalamnya. Asumsiasumi mendasar di dalam sains natural pun bergantung penuh kepada keteraturan di dalam alam yang bersumber dari dan ditopang oleh Allah sendiri, Pencipta yang rasional dan setia kepada perjanjian-Nya. Jaeger mengatakan "The order of natural law, which is necessary for the systematic study of natural causes undertaken by science, is guaranteed both by God's rationality and his faithfulness." 81

Kedua, konsep tindakan ilahi khusus yang memadai akan memperlihatkan kekhususan dari tindakan Allah itu secara objektif dan signifikan. Oleh sebab itu, sebuah konsep tindakan ilahi khusus yang memadai secara teologis harus memperlihatkan dampak signifikan tindakan langsung Allah di dalam jalannya sejarah dunia ini, baik melalui rantai kausalitas penyebab-penyebab natural (yaitu hukum-hukum alam) maupun ketika tidak ada interaksi kausalitas natural apapun yang cukup untuk menghasilkan dampak tersebut (kejadian supranatural seperti mukjizat). Keduanya sama-sama bagian dari providensi Allah yang sedang mengerjakan tujuan-Nya bagi dunia ciptaan. Dengan mengacu kepada keterbukaan alam semesta ini terhadap tindakan Allah maka QM-NIODA bukanlah satu-satunya cara, melainkan hanyalah salah satu cara Allah untuk bertindak di dalam dunia ini. ${ }^{82}$ Selain itu, ketidaklengkapan alam semesta yang terlihat di dalam berbagai tingkatan, baik secara mikro (seperti me-

\footnotetext{
${ }^{81}$ Jaeger, "Against Physicalism-plus-God," 305.

${ }^{82}$ Tracy, salah seorang sarjana yang juga turut bersumbangsih dalam pendekatan NIODA, mengatakan, "As I hope is now clear, I am claiming that this is one possible mode of divine action, and it is certainly not the only way that God's providence can operate" (ibid., 66).
}

kanika kuantum) maupun secara makro (seperti teori Chaos $^{83}$ ) semakin memperlihatkan bahwa untuk membangun sebuah teologi tindakan ilahi khusus yang memadai perlu memasukkan seluruh modus tindakan ilahi, bukan hanya yang nonintervensionis tetapi juga yang intervensionis menurut asumsi DAP. ${ }^{84}$

Dodds menyarankan konsep tindakan ilahi yang memadai harus dikembalikan sepenuhnya dengan mengadopsi pandangan kausalitas Aristoteles yang kemudian diperkenalkan dan dikembangkan lebih lanjut oleh Thomas Aquinas. ${ }^{85}$ Menurut Aristoteles, ada empat mode kausalitas, yaitu material, formal, efisien dan final. Agar lebih mudah memahami keempat mode kausalitas ini, bisa digunakan contoh ilustrasi berikut ini. Seorang pemahat membuat patung seekor kuda dari bahan batu pualam dengan tujuan untuk ditampilkan di dalam sebuah pameran karya seni. Batu pualam sebagai bahan dasar patung tersebut dapat dikatakan sebagai penyebab material dari patung yang akan dibentuk. Bentuk seekor kuda yang ada di benak sang pemahat, yang memandunya selama memahat batu pualam tersebut, dapat dikatakan sebagai penyebab formal. Sang pemahat itu sendiri dapat dikatakan sebagai penyebab efisien, karena dialah yang mengerjakan sendiri proses pemahatan itu supaya batu pualam yang kasar itu bisa dibentuk sedemikian rupa menjadi seekor kuda yang indah. Tujuan dari pembuatan

\footnotetext{
${ }^{83}$ Teori Chaos adalah cabang di dalam ilmu matematika dan fisika yang menyelidiki serangkaian fenomena di dalam dunia yang memperlihatkan dampak yang acak, tidak linear, tidak teratur dan makin lama makin besar dan kompleks, yang awalnya hanya dipicu oleh sebuah kondisi kecil. Teori ini sering digambarkan secara populer sebagai berikut: "Jika seekor kupu-kupu di Cina mengepakkan sayapnya maka akan mengakibatkan badai topan di Brazil."

${ }^{84}$ Tracy juga memasukkan tindakan ilahi khusus yang intervensionis sebagai salah satu cara Allah bertindak. Ia berkata, "God may act directly intervene in an otherwise deterministic secondary causal series (interventionist objectively special action)" (ibid., 65).

${ }^{85}$ Dodds, Unlocking Divine Action, 11-44.
} 
patung kuda ini, yaitu supaya bisa dipamerkan sebagai karya seni, dapat dikatakan sebagai penyebab final. Dengan demikian, ada empat penyebab yang memungkinkan sebuah patung kuda yang indah bisa ditampilkan dalam sebuah pameran karya seni.

Meskipun tidak sempurna, analogi di atas dapat menggambarkan bahwa tindakan Allah di dalam dunia mencakup keempat kausalitas di atas. Tindakan Allah di dalam penciptaan memperlihatkan bahwa Dia adalah penyebab material dan formal bagi segala ciptaan yang ada di dalam alam semesta yang telah dirancang dan dijadikan-Nya itu. Sebagai penyebab material dan formal, Allah tidak hanya berhenti pada penciptaan saja melainkan Dia terus menjaga dan menopang keberadaan ciptaan-Nya dengan providensi-Nya secara umum. Sebagai penyebab efisien bagi segala sesuatu yang terjadi di dalam sejarah dunia ini, Allah dapat bertindak secara tidak langsung maupun langsung. Secara tidak langsung, Ia bertindak melalui penyebab sekunder, seperti proses keteraturan di dalam alam dan makhluk ciptaan-Nya. Allah pun dapat bertindak secara langsung, berupa tindakan ilahi khusus yang nonintervensionis (NIODA) maupun yang terkesan intervensionis seperti mukjizat. Namun, yang sering dilupakan (padahal sangat krusial di dalam teologi tindakan ilahi) adalah bahwa seluruh tindakan Allah sebagai penyebab material, formal dan efisien, diarahkan untuk menggenapi satu tujuan akhir yang dikehendaki-Nya (penyebab final).

Dalam hal inilah kita sampai pada poin ketiga mengenai membangun konsep tindakan ilahi khusus yang memadai, yaitu memperluas cakupan tindakan ilahi yang lebih dari sekadar providensi untuk rentang waktu saat ini saja tetapi providensi di dalam kerangka keseluruhan rencana Allah bagi dunia ini. Sebuah teologi tindakan ilahi khusus yang memadai harus bersifat komprehensif, artinya mampu memperlihatkan keseluruhan cakupan tindakan Allah dari rentang pencip- taan, penebusan hingga penciptaan baru. Sebuah konsep tindakan ilahi yang memadai secara teologis harus diletakkan dalam kerangka keseluruhan rencana Allah secara eskatologis. Kerangka eskatologis ini memayungi seluruh modus tindakan Allah di dalam dunia menjadi satu kesatuan. ${ }^{86}$ Karena itu, sebuah konsep tindakan ilahi khusus yang memadai secara teologis tidak cukup hanya sebatas menjelaskan tindakan penciptaan dan pemeliharaan Allah, tetapi juga harus mencakup tindakan khusus Allah di dalam kebangkitan Kristus serta transformasi alam semesta menjadi ciptaan baru.

Dengan menempatkan keseluruhan tindakan Allah di dalam kerangka teleologis dan eskatologis maka konsep tindakan ilahi yang dibangun sangat memadai dalam pengertian dapat memperlihatkan pribadi Allah yang berdaulat dan transenden, yang sanggup bertindak secara imanen di dalam dunia ini, mulai dari menciptakan, memelihara, dan bahkan mengarahkan seluruh perjalanan sejarah dunia ini kepada tujuan ilahi yang berpuncak pada kebangkitan Yesus Kristus serta berakhir pada transformasi seluruh ciptaan menjadi ciptaan baru.

Secara saintifik, seperti apakah konsep tindakan ilahi khusus yang bersifat trinitarian, kovenantal, kompatibilistik secara theophysical, objektif dan eskatologis? Konsep tindakan ilahi khusus yang diusulkan Jeffrey Koperski mungkin dapat menjadi contoh model. Pandangan Koperski ini disebut neoclassical special divine action (selanjutnya disingkat NCSDA) ${ }^{87}$ Konsep tindakan ilahi ini mengasumsikan dua hal. Pertama, sama seperti para ilmuwan Inggris di awal zaman modern (contohnya Newton dan Boyle), Koperski menilai bahwa fisika atau mekanika

${ }^{86}$ Junghyung Kim, "Toward A Comprehensive Theology of Divine Action," Theology and Science 10, no. 1 (2012): 95

${ }^{87}$ Jeffrey Koperski, Divine Action, Determinism, and the Laws of Nature (London and New York: Routledge 2020), bab 1 . 
klasik tidak mengasumsikan bahwa dunia bersifat tertutup secara mekanis dengan hukum kausal yang deterministik. ${ }^{88}$ Karena itu, kondisi yang indeterministik tidak hanya terjadi di dunia mikro (seperti mekanika kuantum) tetapi juga dapat terjadi di dunia makro. Kedua, hukum-hukum alam tidak dilihat sebagai keberadaan yang independen secara ontologis serta memiliki kapasitas dan energi untuk mengubah atau menghasilkan sesuatu, melainkan sebagai ketetapan Allah yang mengatur segala sesuatu di dalam dunia ini dapat berjalan secara konsisten (dekritalisme).$^{89}$ Keteraturan yang konsisten inilah yang dipahami dan digambarkan oleh para ilmuwan dalam bentuk rumusan atau dalil secara matematis. Dengan dua asumsi mendasar ini, NCSDA melihat hukum-hukum alam sebagai sarana yang dipakai Allah untuk bertindak dengan cara membatasi, mempersempit atau menetapkan satu kemungkinan dari sekian banyak kemungkinan indeterministik yang dapat terjadi di dunia dalam semua tingkatan baik mikro maupun makro. ${ }^{90}$ Tindakan Allah yang demikian tetap dapat diterima secara saintifik karena tidak melanggar hukumhukum alam yang digambarkan secara matematis oleh para ilmuwan. Allah bertindak bukan dengan cara mengubah atau meniadakan hukum-hukum alam, melainkan dengan cara mengubah kondisi nonnomic (tidak terikat hukum alam) dari sebuah peristiwa, seperti kondisi awal dan kondisi yang membatasi. ${ }^{91}$ Dengan demikian, hukum alam tidak dilanggar melainkan siap beradaptasi dan

${ }^{88}$ Koperski, Divine Action, 86, 113-116.

${ }^{89}$ Dekritalisme (decretalism) adalah salah satu pemahaman di dalam filsafat sains mengenai hukum alam sebagai sebuah ketetapan (dekrit) Allah bagi alam semesta (ibid., 86, 100-105).

${ }^{90}$ Ibid., 104.

${ }^{91}$ Ibid., 129-149. Dengan mengambil contoh gambar 1 maka, dalam pandangan NCSDA, tindakan ilahi dapat terjadi ketika Allah mengubah kondisi awal dari posisi piston atau posisi rel penghubung piston menjadi miring beberapa derajat. Tindakan Allah juga bisa terjadi ketika Ia menetapkan sebuah kondisi yang membatasi pergerakan piston atau pergerakan roda, misalnya gaya gesek. berubah mengikuti keadaan yang ada. NCSDA mampu memperlihatkan tindakan ilahi khusus secara objektif dan signifikan karena tidak terbatas hanya mencari titik temu kausal tertentu atau indeterminisme secara ontologis di dalam proses-proses natural karena Allah dapat bertindak di dalam dan melalui seluruh proses tersebut.

\section{KESIMPULAN}

Tulisan ini telah mengkaji asumsi-asumsi filosofis di balik konsep tindakan ilahi khusus yang diusulkan DAP dan memperlihatkan bahwa pendekatan NIODA dan juga para sarjana yang mencetuskannya masih terikat di dalam asumsi "Setan Laplace" bahwa alam semesta ini bersifat tertutup secara kausal sehingga hukum-hukum alam dipahami secara ontologis-preskriptif dan tindakan ilahi khusus yang dianggap sahih hanyalah yang inkompatibel dengan penyebab natural, nonintervensionis dan indeterministik secara ontologis. Akibatnya, konsep tindakan ilahi yang diusulkan lebih condong supaya bisa diterima secara saintifik namun tidak memadai secara teologis. Karena itu, asumsiasumsi filosofis DAP dan NIODA yang masih mengacu kepada warisan zaman pencerahan perlu didekonstruksi dan direkonstruksi dengan melibatkan asumsi-asumsi teologis yang memadai. Konsep tindakan ilahi khusus yang memadai secara teologis perlu dibangun di atas fondasi teologi penciptaan yang menonjolkan dualitas relasi Allah Pencipta dengan dunia ciptaan secara trinitarian dan kovenantal. Teologi tindakan ilahi yang demikian akan memperlihatkan bahwa dunia natural tidak bersifat tertutup bagi Allah karena hukum-hukum alam tidak bersifat otonom secara ontologis dan preskriptif, melainkan sebagai ekspresi deskriptif dari ketetapan preskriptif Allah Tritunggal sendiri yang menata dan mengatur alam semesta ini secara konsisten di dalam kedaulatan dan kesetiaan-Nya kepada perjanjian-Nya.

Sebuah konsep tindakan ilahi khusus yang 
dibangun di atas fondasi teologi penciptaan yang trinitarian-kovenantal juga dapat memadai secara saintifik karena memperlihatkan kompatibilitas antara kebebasan tindakan Allah dengan rantai kausalitas hukumhukum alam. Dengan kompatibilitas seperti ini, Allah dapat bebas bertindak tidak hanya diperantarai oleh penyebab-penyebab natural (hukum-hukum alam) saja tetapi juga bisa melalui cara-cara lain secara langsung dan khusus yang melampaui hukum alam, tanpa melanggar hukum tersebut. Dan yang terakhir, sebuah konsep tindakan ilahi khusus yang memadai akan memperlihatkan keaktifan Allah yang berdaulat dan transenden, yang sanggup bertindak secara imanen di dalam dunia ini, bukan hanya menciptakan dan memelihara alam semesta ini, namun juga menebus dan mengubahkannya menjadi ciptaan baru serta mengarahkannya kepada konsumasi dari tujuan kekal yang dikehendaki-Nya di dalam Kristus.

Sebuah model tindakan ilahi khusus yang memadai secara teologis dan saintifik akan melihat kembali kepada fisika klasik namun dari sudut pandang yang baru, yaitu alam semesta tidak bersifat deterministik semata namun juga memperlihatkan adanya situasi dan kondisi yang indeterministik. Allah dapat saja bertindak di dalam dunia melalui kedua jenis kondisi tersebut tanpa melanggar hukum-hukum alam yang telah ditetapkan-Nya dari sejak dunia diciptakan.

\section{DAFTAR KEPUSTAKAAN}

Aczel, Amir D. Why Science Does Not Disprove God? New York: William Morrow/Harper-Collins, 2014.

Calvin, John. Institutes of the Christian Religion. Vol. 1. Diedit oleh John T. McNeil. Diterjemahkan oleh Ford Lewis Battles. Louisville: WJK, 2006.

Clayton, Philip. "Wildman's Kantian Skepticism: A Rubicon for the Divine Action Debate." Theology and Science 2, no. 2 (2004): 186-190.
Brooke, John Hedley. "Divine Providence in the Clockwork Universe." Dalam Abraham's Dice: Chance and Providence in the Monotheistic Traditions, diedit oleh Karl W. Giberson, 215-239. New York: Oxford University Press, 2016.

Cross, Simon J.S. "Perspectives on Divine Action: Reflections on the Theological Legitimacy of Approaches to Divine Action in the V.O./C.T.N.S. Series 'Scientific Perspectives on Divine Action'.' Disertasi, University of Oxford, 2017.

Dodds, Michael J. Unlocking Divine Action. Washington: The Catholic University of America Press, 2017.

Gregersen, Niels Henrik. "Divine Action and the Quilt of Laws: Why the Distinction between General and Special Divine Action Cannot Be Maintained." Dalam Scientific Perspectives on Divine Action: Twenty Years of Challenge and Progress, diedit oleh Robert J. Russell, Nancey Murphy, dan William R. Stoger, 179-200. Notre Dame: University of Notre Dame Press, 2008.

Harrison, Peter. "Voluntarism and Early Modern Science." History of Science 40, no. 1 (2002): 63-89.

Jacobs, Andrew. "The Creative Power of the Future: Wolfhart Pannenberg, Modern Science, and the Metaphysics of Divine Action." Disertasi, Fordham University, 2009.

Jaeger, Lydia. "Against Physicalism-plusGod: How Creation Accounts for Divine Action in the World." Faith and Philosophy 29, no. 3 (2012): 295-312.

Jones, Kile. "Falsifiability and Traction in Theories of Divine Action." Zygon 45, no. 3 (2010): 575-589.

Kim, Junghyung. "Toward A Comprehensive Theology of Divine Action." Theology and Science 10, no. 1 (2012): 95-101.

Koperski, Jeffrey. The Physics of Theism: God, Physics and The Philosophy of Science. Chichester: Wiley-Blackwell, 2015.

- "The Quantum Amplification Problem Appears to Be Unsolvable." 
Theology and Science 13, no. 4 (2015): 378-393.

- Divine Action, Determinism and the Laws of Nature. London and New York: Routledge, 2020.

Laplace, Pierre-Simon. A Philosophical Essay on Probabilities. London: John Wiley and Sons, 1902.

Lighthill, James. "The Recently Recognized Failure of Predictability in Newtonian Dynamics." Dalam Proceedings of the Royal Society A: Mathematical, Physical and Engineering Sciences 407 (1986): 3550.

Mackie, John L. The Miracle of Theism: Arguments for and against the Existence of God. New York: Oxford University Press, 1982.

Morris, Tim dan Don Petcher. Science and Grace: God's Reign in the Natural Sciences. Wheaton: Crossway, 2006.

Newton, Isaac. Opticks. 1730. Reprint, New York: Dover, 1952.

Plantinga, Alvin. Where The Conflict Really Lies: Science, Religion, and Naturalism. Oxford: Oxford University Press, 2011.

Poe, Harry Lee, dan Jimmy H. Davis. God and the Cosmos: Divine Activity in Space, Time and History. Downers Grove: IVP Academic, 2012.

Polkinghorne, John C. "Chaos Theory and Divine Action." Dalam Religion and Science: History, Method, Dialogue, diedit oleh Mark W. Richardson dan Wesley J. Wildman, 243-254. New York: Routledge, 1996.

Poythress, Vern S. "Why Scientist Must Believe in God: Divine Attributes of Scientific Law." Journal of the Evangelical Theological Society 46, no. 1 (2003): 111-123.

Ritchie, Sarah Lane. "Dancing Around the Causal Joint: Challenging the Theological Turn in Divine Action Theories." Zygon 52, no. 2 (2017): 361-379.

- Divine Action and the Human Mind. Cambridge: Cambridge University Press, 2019.

Russell, Robert John. Cosmology: From
Alpha to Omega. Minneapolis: Fortress, 2008.

- "Challenge and Progress In 'Theology And Science': An Overview Of The CTNS/VO Series." Dalam Philosophy, Science and Divine Action, diedit oleh F. Leron Shults, Nancey Murphy, dan Robert J. Russell, 407-426. Leiden: Brill, 2009.

_. "Quantum Physics and the Theology of Non-Interventionist Objective Divine Action." Dalam The Oxford Handbook of Religion and Science, di-edit oleh Philip Clayton dan Zachary Simpson, 579-595. Oxford: Oxford University Press, 2006.

Saunders, Nicholas. Divine Action and Modern Science. Cambridge: Cambridge University Press, 2002.

—. "Does God Cheat at Dice? Divine Action and Quantum Possibilities." Zygon 35, no. 3 (2000): 517-544.

Smedes, Taede A. "Beyond Barbour or Back to Basics? The Future of Science-andReligion and the Quest for Unity." Zygon 43, no. 1 (2008): 235-258.

Sober, Elliott. "Why Methodological Naturalism?" Dalam Biological Evolution: Facts and Theories: A Critical Appraisal 150 Years After the Origin of Species, diedit oleh G. Auletta, M. Leclerc, dan R. A. Martinez, 359-378. Roma: Gregorian and Biblical Press, 2011.

Stoeger, William. "Epistemological and Ontological Issues Arising from Quantum Theory." Dalam Quantum Mechanics: Scientific Perspectives on Divine Action, diedit oleh Robert John Russell, Philip Clayton, K. Wegter-McNelly, dan John C. Polkinghorne, 81-98. Vatican City: Vatican Observatory Publication, 2001.

Tracy, Thomas. "Scientific Perspectives on Divine Action? Mapping the Options." Theology and Science 2, no. 2 (2004): 196-201.

VanDrunen, David. Divine Covenants and Moral Order: A Biblical Theology of $\mathrm{Na}$ tural Law. Grand Rapids: Eerdmans, 2014. 
Wildman, Wesley J. "Robert John Russell's Theology of God's Action." Dalam God's Action in Nature's World, diedit oleh Ted Peters dan Nathan Hallanger, 147-170. New York: Routledge, 2016.

. "The Divine Action Project, 19882003." Theology and Science 2, no. 1 (2004): 31-75.
Wilson, Mark. "Critical Notice: John Earman's A Primer on Determinism." Philosophy of Science 56, no. 3 (1989): 502-532.

Wright, Christopher J.H. Knowing the Holy Spirit Through the Old Testament. Downers Grove: InterVarsity, 2006. 